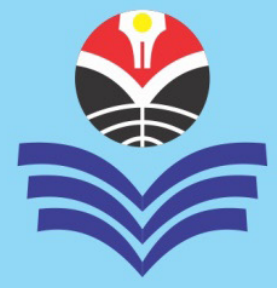

\title{
Pers dan Kritik Sosial pada Masa Orde Baru: Studi Kasus Pers Mingguan Mahasiswa Indonesia di Bandung, 1966-1974
}

\begin{abstract}
ABSTRAKSI: Artikel ini, dengan menggunakan pendekatan kualitatif dan metode historis, mengkaji tentang dinamika politik pada masa-masa awal Orde Baru (1966-1974) di Indonesia, dengan memfokuskan analisis mengenai pers dan kritik sosial. Studi difokuskan pada mingguan "Mahasiswa Indonesia" di Bandung, yang bersikap kritis terhadap masalah-masalah yang membelenggu pemerintah Orde Baru pada masa itu. Hasil kajian menunjukan bahwa fenomena KKN (Korupsi, Kolusi, dan Nepotisme) pada masa-masa awal pemerintah Orde Baru, seperti kedudukan SPRI (Staf Pribadi) Presiden; kasus BULOG (Badan Urusan Logistik); dan masalah pembangunan TMII (Taman Mini Indonesia Indah) di Jakarta, menjadi "news and views" (berita dan pandangan) yang kritis dari mingguan "Mahasiswa Indonesia". Namun, berbagai reaksi tersebut tidak menggoyahkan kedudukan pemerintah Orde Baru dalam rangka membangun konsolidasi kekuasaan dan legitimasi pemerintahan. Bahkan pers yang kritis, termasuk mingguan "Mahasiswa Indonesia" di Bandung, akhirnya dibungkam oleh pemerintah Orde Baru, dan sepertinya rejim ini tidak akan tergoyahkan untuk masa 20 tahunan ke depan.
\end{abstract}

KATA KUNCI: Pers dan Kritik Sosial; Pemerintah Orde Baru; Mingguan "Mahasiswa Indonesia"; Masalah Korupsi, Kolusi, dan Nepotisme.

ABSTRACT: "Press and Social Criticism in the New Order Period: Case Study of Indonesian Student Weekly in Bandung, 1966-1974". This article, using a qualitative approach and historical methods, examines the political dynamics in the early period of the New Order (1966-1974) in Indonesia, by focusing on analysis of the press and social criticism. The study focused on the weekly of "Indonesian Students" in Bandung, which were critical towards the problems that bound the New Order government at that time. The results of the study showed that the phenomena of KKN (Corruption, Collusion, and Nepotism) in the early period of the New Order government, such as the position of the SPRI (Personal Staff) of the President; BULOG (Logistics Affairs Agency) case; and the problem of developing of TMII (Beautiful Indonesian Miniature Garden) in Jakarta, becoming a critical news and views from the weekly of "Indonesian Students". However, these various reactions did not destabilize the position of the New Order government in the context to build a consolidation of government power and legitimacy. Even the critical press, including the weekly of "Indonesian Students" in Bandung, was finally silenced by the New Order government, and it seems that this regime will not be deterred for the next 20 years.

KEY WORD: Press and Social Criticism; New Order Government; "Indonesian Students" Weekly; Problems of Corruption, Collusion, and Nepotism.

About the Author: Andi Suwirta, M.Hum. adalah Dosen Senior di Departemen Pendidikan Sejarah FPIPS UPI (Fakultas Pendidikan Ilmu Pengetahuan Sosial, Universitas Pendidikan Indonesia) di Bandung, Jawa Barat, Indonesia; dan Sekretaris Jenderal ASPENSI (Asosiasi Sarjana Pendidikan Sejarah Indonesia) Periode 2018-2023. Untuk kepentingan akademik, penulis bisa dihubungi dengan alamat emel: atriwusidna@gmail.com

Suggested Citation: Suwirta, Andi. (2018). "Pers dan Kritik Sosial pada Masa Orde Baru: Studi Kasus Pers Mingguan Mahasiswa Indonesia di Bandung, 1966-1974” in MIMBAR PENDIDIKAN: Jurnal Indonesia untuk Kajian Pendidikan, Volume 3(2), September, pp.113-136. Bandung, Indonesia: UPI [Indonesia University of Education] Press, ISSN 2527-3868 (print) and 2503-457X (online).

Article Timeline: Accepted (December 27, 2017); Revised (May 20, 2018); and Published (September 30, 2018). 


\section{PENDAHULUAN}

Pemerintah Orde Baru, di bawah kepemimpinan Jenderal Soeharto, lahir dalam suasana krisis ekonomi, kekalutan politik, dan huru-hara sosial yang terjadi sekitar pertengahan tahun 1960-an. Namun begitu, kehadiran pemerintah Orde Baru pada awalnya disambut dengan suka-cita dan hangat oleh sebagian besar masyarakat Indonesia. Tidak terkecuali para mahasiswa, aktivis, dan pihak-pihak yang selama masa pemerintahan Orde Lama, di bawah kepemimpinan Presiden Soekarno, merasa dikecewakan. Banyak sekali harapan masyarakat terhadap pemerintahan baru ini. Mereka berharap agar pemerintah Orde Baru dapat membawa bangsa Indonesia kepada kehidupan yang jauh lebih baik lagi (Poesponegoro \& Notosusanto eds., 1991; Vatikiotis, 1998; dan Affan, 2013).

Orde Baru lahir secara dramatis pada tahun 1966, ketika bangsa Indonesia mengalami suatu perubahan orientasi yang luar biasa di segala bidang, baik dalam bidang politik, ideologi, dan ekonomi maupun sosial dan kebudayaan. Dalam konteks ini, kelompok TNI-AD (Tentara Nasional Indonesia - Angkatan Darat), di bawah pimpinan Jenderal Soeharto, secara bertahap menerima pengalihan kekuasaan dari Presiden Soekarno dan mulai menata kembali masyarakat Indonesia. Masa konsolidasi kekuasaan pemerintah Orde Baru (1966-1974) tersebut ditandai dengan pencarian legitimasi dan rekonstruksi di segala bidang. Tiga pilar utama yang diharapkan dapat menopang kekuatan pemerintah Orde Baru, yaitu Birokrat, Teknokrat dan Tentara itu sendiri (Milne, 1984; Mas'oed, 1989; Muhaimin, 1990; dan Rajab, 2004).

Rentangan waktu antara 1966-1974 merupakan masa di mana bangsa Indonesia sedang menata kembali berbagai bidang kehidupan. Berakhirnya masa pemerintah Orde Lama (1959-1966) dan lahirnya pemerintah Orde Baru menuntut adanya perbaikan instalasi-instalasi penting, yang pada masa itu keadaannya kacaubalau dan terabaikan. Dalam hal ini, Eep Saefullah Fatah (1999) menyatakan tentang perlunya memahami fase pertama dalam perjalanan kehidupan sebuah rezim Orde Baru ditegakkan. Fase pertama adalah konsolidasi awal pemerintahan Orde Baru (1967-1974). Dalam fase ini rezim Orde Baru terbentuk dan sedang menata aliansi di dalam dirinya secara internal. Jenderal Soeharto sendiri belum mempunyai kekuatan penuh, bahkan pada awalnya ia kurang diperhitungkan banyak orang. Jenderal Soeharto masih merupakan bagian dari kekuatan militer secara kolektif, belum menjadi kekuasaan politik yang mandiri. Namun ketika melewati masa peristiwa MALARI (Malapetaka 15 Januari) tahun 1974, Jenderal Soeharto mulai menunjukan otoritasnya lewat pemerintahan, terutama dalam hal menyikapi berbagai masalah dan berusaha semakin menunjukan usaha untuk membangun Indonesia (cf McDonald, 1980; Liddle, 1992; Fatah, 1999; dan Elson, 2001).

Tahun 1966-1974 adalah juga masa di mana pemerintah Orde Baru selain melakukan pembangunan, juga bersamaan dengan itu melakukan berbagai upaya untuk mengkonsolidasikan kekuasaannya. Berbagai strategi mulai diterapkan dan berbagai pengaruh mulai ditanamkan dalam bidang kehidupan. Langkahlangkah tersebut bukan berarti tanpa hambatan. Nilai-nilai modernisasi mulai dipropagandakan dan ideologi pembangunan juga mulai dikembangkan. Pada masa itu dikembangkan sebuah strategi pembagunan nasional, yang terutama dilakukan oleh kaum intelektual di sekeliling Mayor Jenderal Ali Moertopo, salah seorang yang sangat dekat dengan pusat kekuasaan dan termasuk elite lingkaran dalam Presiden Soeharto (Moertopo, 1974; Glassburner, 1988; Mas'oed, 1989; dan Jenkins, 2010).

Strategi pembangunan nasional itu tidak hanya meliputi pembangunan ekonomi, 
pembuatan kebijakan secara rasional, efisien, efektivitas, dan pragmatisme, tetapi juga ditekankan masalah ketertiban dalam versi pemerintah. Hal ini nampaknya sejalan dengan tujuan pembangunan ekonomi pemerintah Orde Baru, sebagaimana dinyatakan oleh Mohtar Mas'oed (1989), sebagai berikut:

Pemerintah baru diarahkan untuk membuat kue nasional menjadi lebih besar, paling tidak sebagai prioritas utama. Widjojo Nitisastro mengatakan bahwa pembangunan yang lebih merata membutuhkan pertumbuhan ekonomi [...] mungkin hanya merupakan suatu tujuan antara tetapi pernyataan para elite tentang pembangunan jelas menekankan sebagai tujuan yang paling penting. [...] Soeharto menggambarkan stabilitas, ketertiban, dan keamanan sebagai tujuan tersendiri yang dapat menciptakan rasa aman secara fisik dan hati pada masyarakat (Mas'oed, 1989:145).

Sementara itu, prinsip dasar dari pemerintah Orde Baru adalah keinginan untuk menegakkan suatu rezim orde pembaharu yang bukan hanya sekedar menggantikan rezim yang lama. Kata "modernisasi dan pembangunan" adalah slogan yang selalu digembar-gemborkan oleh pemerintah Orde Baru, sebagai tujuan utama yang hendak dicapai oleh Jenderal Soeharto. Ia menawarkan stabilisasi dan pembangunan. Dan berdasarkan penekanan ideologis Orde Baru pula, maka kabinet yang dibentuk oleh Jenderal Soeharto pun dinamakan "Kabinet Pembangunan" (Raillon, 1985; Mas'oed, 1996; Affan, 2013; dan Khoir, 2014).

Dalam hal stabilisasi ekonomi, banyak yang harus segera diperbaharui oleh pemerintah Orde Baru, sebagai warisan dari pemerintah Orde Lama (1959-1966), seperti: hutang luar negeri yang begitu besar; nilai ekspor yang jatuh; rusaknya sejumlah infrastuktur, karena tidak adanya perawatan; inflasi yang begitu hebat hingga mencapai $650 \%$ dan masalah-masalah lain sebagai akibat politik ekonomi yang tanpa perhitungan; serta juga proyek-proyek yang dibuat hanya sekedar untuk prestise belaka dari pemerintah Orde Lama (Hill, 2002; Kuncoro, 2010; dan Pujoalwanto, 2014). Namun kesukaran-kesukaran yang harus segera diatasi oleh pemerintah Orde Baru sebenarnya hanya merupakan lanjutan dari satu keadaan lain yang lebih penting, yaitu memperbaiki struktur ekonomi dan sosial-politik dari dasar lagi. Memang bukanlah tugas yang mudah bagi rezim Orde Baru untuk mengadakan stabilisasi dan rehabilitasi ekonomi, sosial, dan politik bangsa pada masa-masa awal pemerintahannya (Both \& McCawley, 1983; Hill, 1997 dan 2002; Crouch, 1999; dan Luiten \& Marks, 2012).

Orde Baru lahir dengan setumpuk tugas berat, akibat sekian lama diabaikan oleh pemerintahan sebelumnya, terutama dalam masalah pembangunan ekonomi. Sehingga akhirnya sebagai Presiden, Jenderal Soeharto, memutuskan untuk membawa sekelompok teknokrat dari UI (Universitas Indonesia) di Jakarta ke pusat pemerintahannya dalam Presidium Kabinet. Kelompok teknokrat dari UI, yang dipimpin oleh Prof. Dr. Widjojo Nitisastro, dipercaya untuk merancang dan melaksanakan pembangunan ekonomi secara bertahap dan berkelanjutan (Both \& McCawley, 1983; Vatikiotis, 1998; Hill, 2002; dan Anwar, Ananta \& Kuncoro eds., 2007).

Namun sejak awal, dalam pemerintahan Jenderal Soeharto, terjadi ada semacam dualisme. Di samping wakil-wakil menteri dalam kabinet yang membantu tugastugas Presiden, ternyata Jenderal Soeharto juga dikelilingi oleh power central lainnya. Hal ini seringkali menyebabkan adanya perbenturan kepentingan antara kaum intelektual yang sedang mencoba membuat terobosan-terobosan dalam hal pembangunan ekonomi dengan para perwira TNI-AD (Tentara Nasional Indonesia - Angkatan Darat), yang dekat dengan Presiden Soeharto (Mas'oed, 1996; 
Cahyono, 1998:18; Rajab, 2004; dan Jenkins, 2010).

Posisi para perwira TNI-AD dalam pembentukan dan perkembangan kokohnya rezim Orde Baru, di bawah kepemimpinan Jenderal Soeharto, memang begitu dominan dalam pemerintahan setelah tahun 1966. Bahwa para perwira TNI-AD tidak hanya menganggap dirinya sebagai stabilisator, namun juga sekaligus sebagai dinamisator, serta mampu memberikan pembaharuan dan perbaikan ekonomi bangsa, nampaknya bercermin dari pemerintahan sebelumnya yang telah gagal akibat dominasi politik dari pihak politisi sipil (Crouch, 1999; Elson, 2001; dan Jenkins, 2010).

Sebagai kekuatan nasional yang mengidentifikasikan dirinya sebagai "Pejuang dan Prajurit", yang selalu hirau dengan kepentingan masyarakat umum, para perwira TNI-AD berkeyakinan bahwa pemerintahan yang didominasi oleh tentara akan menjamin terpeliharanya kestabilan politik yang dibutuhkan untuk pembangunan ekonomi, sebagaimana dicita-citakan oleh pemerintah Orde Baru. Dalam pandangan pihak TNI-AD bahwa stabilitas akan mendorong inventasi, baik dari dalam maupun luar negeri, untuk kepentingan pembangunan ekonomi secara berkelanjutan dan dalam jangka panjang (Moertopo, 1974; Muhaimin, 1982; Sundhaussen, 1987; Notosusanto et al. eds., 1991; Crouch, 1999; Istyaningrum, 2004; dan Jenkins, 2010).

Pada tahun-tahun permulaan Orde Baru didirikan, Jenderal Soeharto banyak memberikan keleluasaan bergerak bagi para perwira TNI-AD, terutama mereka yang berasal dari Divisi Dipenegoro di Jawa Tengah, tempat Jenderal Soeharto berkarier dan menempa dirinya sebagai tentara. Dalam hal ini, Harold Crouch (1999) menyebut para perwira yang dekat dengan kekuasaan Presiden Soeharto itu sebagai "Jenderaljenderal Politik dan Uang”, sebuah sebutan dengan konotasi yang buruk, karena dianggap sebagai sumber KKN atau Korupsi, Kolusi, dan Nepotisme ( $c f$ Tjahjono, 1979; Crouch, 1999; dan Jenkins, 2010).

Berbagai kebijakan telah dipikirkan, digodog, dan dibuat oleh suatu kelompok perwira TNI-AD, yang telah dipilih dan dipercaya oleh Presiden Soeharto. Deputi Panglima TNI-AD, misalnya, dijabat oleh Letnan Jenderal Maraden Panggabean, seorang perwira tinggi dari suku Batak dan beragam Kristen, yang sangat loyal kepada Jenderal Soeharto. Begitu juga dengan posisi Menteri Dalam Negeri, dijabat oleh Mayor Jenderal Basuki Rahmat, salah seorang perwira TNI-AD yang membawa SUPERSEMAR (Surat Perintah 11 Maret) tahun 1966, senjata utama Jenderal Soeharto untuk menjatuhkan Presiden Soekarno pada tahun 1966-1968. Posisi Menteri Dalam Negeri ini jelas sangat strategis, karena memiliki pengaruh besar dalam bidang politik, keamanan, dan ketertiban umum di Indonesia (Vatikiotis, 1998; Fatah, 1999; Crouch, 1999; Rajab, 2004; dan Jenkins, 2010).

Sementara itu, penguasaan minyak dan barang tambang lainnya dipercayakan kepada Mayor Jenderal Ibnu Sutowo, seorang perwira tinggi TNI-AD yang akan memimpin PERTAMINA (Perusahaan Tambang Minyak Nasional) pada tahun 1970-an. Manakala masalah BULOG (Badan Urusan Logistik) secara nasional dikepalai oleh Brigadir Jenderal Achmad Tirtosudiro, seorang perwira tinggi TNIAD dan Muslim yang taat, yang menguasai sepenuhnya perdagangan bahan-bahan kebutuhan pokok, khususnya beras dan bahan pangan lainnya. Sedangkan Brigadir Jenderal Suhardiman menguasai perusahaan dagang raksasa, seperti PT BERDIKARI (Perseroan Terbatas Berdiri Diatas Kaki Sendiri), yang telah diambil-alih dari pemerintah Orde Lama, karena mengalami masalah salah-urus dan kerugian ekonomi lainnya (Shundaussen, 1987; Mas'oed, 1989; Muhaimin, 1990; Crouch, 1999; dan Jenkins, 2010).

Meskipun begitu, di dalam pemerintahan 
Orde Baru juga diikutsertakan berbagai tokoh dari kalangan sipil untuk memanfaatkan keahlian dan pengalaman mereka. Hal ini dilakukan juga untuk menciptakan suasana atau kesan di dalam negeri yang positif terhadap Orde Baru, sebagai pemerintahan yang bukan junta militer, dimana semua posisi-posisi penting dalam negara dikuasai sepenuhnya oleh tentara. Begitu juga bahwa pemerintah Orde Baru ingin menciptakan gambaran yang baik terhadap negara-negara Barat, yang turut memberi bantuan keuangan kepada pemerintah Orde Baru, sebagai pemerintahan yang demokratis dan menjamin hak-hak sipil kepada warga negaranya (Milne, 1984; Crouch, 1999:268269; Istyaningrum, 2004; dan Rajab, 2004).

Memang, bukan suatu tugas yang mudah bagi Jenderal Soeharto untuk memangku jabatan sebagai Presiden Indonesia pada masa-masa awal Orde Baru. Banyak pihak, terutama dari perwira-perwira tentara sendiri yang tidak menyukai kemunculannya begitu cepat dalam kekuasaan, dan akan menjadi penentangnya yang kuat. Begitu juga dengan para mahasiswa yang tidak puas dengan gaya pemerintahan Jenderal Soeharto, yang mengesankan sikap alon-alon waton kelakon (pelan-pelan tetapi tercapai tujuan), dalam merespons masalah-masalah politik dan pembangunan ekonomi di Indonesia. Proses konsolidasi kekuasaan dan mencari legitimasi politik yang kuat inilah yang menjadi masa-masa kritis pemerintahan Orde Baru pada akhir tahun 1960-an dan awal tahun 1970-an (McDonald, 1980; Roeder, 1981; Soeharto, 1989; Crouch, 1999; dan Elson, 2001).

Artikel ini, dengan menggunakan pendekatan kualitatif dan metode historis (Notosusanto, 1984; Kartodirdjo, 1992; Zed, 2004; Sjamsuddin, 2007; dan Denzin, 2008), mengkaji tentang dinamika politik bangsa Indonesia pada masa-masa awal Orde Baru, dengan memfokuskan analisis mengenai pers dan kritik sosial terhadap pemerintah Orde Baru pada masa-masa awal membangun pemerintahannya. Dalam konteks ini menjadi menarik untuk mengkaji tentang kelahiran mingguan Mahasiswa Indonesia di Bandung; mengetahui sikap dan pandangan mingguan Mahasiswa Indonesia dalam menyoroti masalah KKN (Korupsi, Kolusi, dan Nepotisme) pada masa-masa awal Orde Baru; serta mengetahui reaksi dan tindakan Orde Baru terhadap sikap dan pandangan pers yang bersifat kritis kepada pemerintah.

\section{HASIL DAN PEMBAHASAN} Mengenai Kelahiran Mingguan “Mahasiswa Indonesia” di Bandung. Mingguan Mahasiswa Indonesia lahir di tengah-tengah kondisi bangsa yang sedang mengalami gejolak. Pada tanggal 19 Juni 1966 terbitlah nomor perdana Mahasiswa Indonesia, edisi Jawa Barat. Mingguan Mahasiswa Indonesia ini berbentuk tabloit, dengan ukuran $30 \mathrm{x}$ $45 \mathrm{~cm}$ (centimeter), tebalnya 8 halaman, ditambah 2 halaman untuk iklan. Mingguan Mahasiswa Indonesia menuliskan motto di bawah namannya, yakni: "Pembina Insan Pantjasila". ${ }^{1}$

Pada nomor perdana, isi mingguan Mahasiswa Indonesia masih agak sederhana, yakni baru memuat 5 artikel dan sebuah editorial tentang sidang MPRS (Majelis Permusyawaratan Rakyat Sementara) yang akan datang, tahun 1967. Namun meskipun begitu, edisi ini mempunyai arti penting. Dilihat dari keterangan yang redaksi cantumkan tentang pengurus (daftar nama anggota), pendukung lahirnya mingguan Mahasiswa Indonesia adalah dari berbagai tokoh yang penting pada masa itu. Namanama itu menggambarkan seperti layaknya sebuah seri artikel pendek, jika melihat panjangnya daftar pengurus dan anggota

\footnotetext{
${ }^{1}$ Mingguan Mahasiswa Indonesia (Bandung: 19 Juni 1966), hlm.1. Lihat juga, misalnya, studi yang dilakukan oleh Amir Effendi Siregar (1983); Francois Raillon (1985); Akhmad Zaini Abar (1995); dan Satrio Arismunandar (2012).
} 
pendukung mingguan Mahasiswa Indonesia di Bandung (Siregar, 1983; Raillon, 1985; Abar, 1995; dan Arismunandar, 2012).

Mingguan Mahasiwa Indonesia, yang terbit di Bandung ini, alamat redaksinya adalah menempati kantor di Jalan Tamblong No.1, Kota Bandung, Jawa Barat. Mingguan ini memang tidak bertahan lama, dan mungkin orang tidak mengenal lagi bahwa pernah hadir sebuah pers, berupa mingguan, yang penting di Bandung pada tahun 1960-an hingga tahun 1970-an; atau hanya sebagian kecil kalangan saja yang masih mengenal keberadaan dan peran mingguan Mahasiswa Indonesia sampai sekarang ini (Siregar, 1983; Raillon, 1985; Abar, 1995; Arismunandar, 2012; dan wawancara dengan Rachman Tolleng, 12/3/2001).

Namun pada masanya, dari mulai penerbitan yang pertama, mingguan Mahasiswa Indonesia sudah mendapat tanggapan besar dari berbagai kalangan, terutama dari kalangan intelektual yang menyambut positif hadirnya pemerintahan Orde Baru. Karena memang lebih dari 57\% isi mingguan Mahasiswa Indonesia itu memuat berbagai berita politik dan masalah sosial yang menarik perhatian. Bebagai berita, pandangan, dan analisisnya menjadi kosumsi tidak hanya bagi kalangan mahasiswa, namun juga bagi kalangan intelektual lainnya serta masyarakat umum (Junaedhie, 1991; Abrar, 1992; Abar, 1995; dan Muhdar, 2012). Dalam konteks ini, Amir Effendi Siregar (1983) menyatakan bahwa mingguan Mahasiswa Indonesia memang lebih banyak memuat berita politik dibandingkan dengan dua koran mahasiswa lainnya, yaitu Harian KAMI di Jakarta dan Mimbar Demokrasi di Bandung, yang terbit dan berkembang pada masa yang sama dengan mingguan Mahasiswa Indonesia di Bandung (Siregar, 1983).

Dalam perkembangan selanjutnya, mingguan Mahasiswa Indonesia didirikan oleh 3 orang yang menjadi Pemimpin Umumnya, yaitu: S. Ryandi, Awan
Karmawan Burhan, dan Iwan Ramelan (Rachman Tolleng). Nama yang terakhir inilah yang menjadi motor penggerak, sekaligus pekerja, dari mingguan Mahasiswa Indonesia di Bandung. Rachman Tolleng juga yang memegang tampuk Pimpinan Redaksi sampai dengan mingguan ini ditutup pada tahun 1974.

Sekurang-kurangnya sampai dengan tahun 1972, Rachman Tolleng merupakan seorang Pemimpin Redasi, Pemimpin Umum, dan Penanggung Jawab mingguan Mahasiswa Indonesia di Bandung, yang menggariskan dan mengontrol haluan redaksi mingguan ini. Ia juga sering menulis editorial; karena itu, seringkali dikatakan bahwa mingguan Mahasiswa Indonesia sebagai korannya Rachman Tolleng (Siregar, 1983; Raillon, 1985; Abar, 1995; dan wawancara dengan Rachman Tolleng, 12/3/2001). Lihat gambar 1.

Pada waktu mulai diterbitkan, mingguan Mahasiswa Indonesia di Bandung mempunyai stuktur yang masih sederhana sekali. Mingguan Mahasiswa Indonesia memiliki susunan staf redaksi dan administrasi yang tidak tetap. Di sana memang tercantum banyak nama mahasiswa anggota KAMI (Kesatuan Aksi Mahasiswa Indonesia) dari Jakarta dan Bandung, seperti: Bonar Siagian, Alex Rumodor, Kusnaka Adimihardja, Soe Hoek Gie, Yozar Anwar, Jahja Wullur, M.T. Zein, dan Sudjoko. Mereka pada umumnya adalah para mahasiswa dari UI (Universitas Indonesia) di Jakarta, ITB (Institut Teknologi Bandung), dan UNPAD (Universitas Padjadjaran) Bandung. Bahkan Mohtar Lubis, seorang intelektual dengan reputasi nasional, juga ikut mewarnai halaman Mahasiswa Indonesia, meskipun hanya terdiri dari beberapa artikel saja. Ditambah lagi dengan belasan nama-nama mahasiswa lainnya yang kurang dikenal pada tahun 1966, namun pengalaman mereka di bidang pers banyak berkecimpung dalam penerbitan-penerbitan mahasiswa di kampus, seperti: Berita ITB, Campus, 


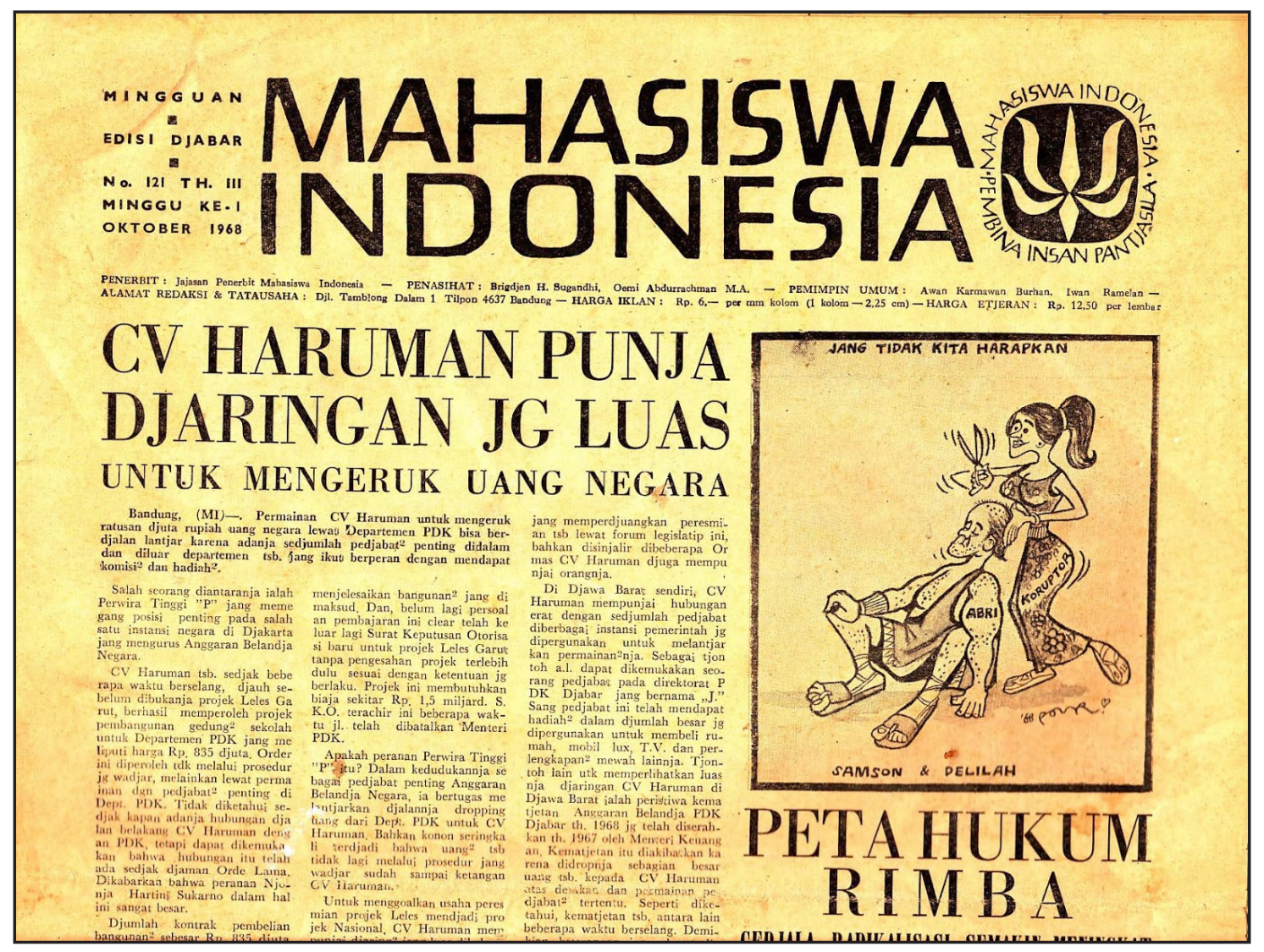

\section{Gambar 1:}

"Mingguan Mahasiswa Indonesia di Bandung"

(Sumber: http://koleksikemalaatmojo2.blogspot.com, 9/10/2017)

dan lain-lain (Siregar, 1983; Raillon, 1985; Junaedhie, 1991; Abar, 1995; Maxwell, 2001; Supriyatna, 2007; dan Arismunandar, 2012).

Terbitnya mingguan Mahasiswa Indonesia di Bandung ini mendapat dukungan pula dari tokoh-tokoh utama pemerintah Orde Baru. Dalam hal ini, Francois Raillon (1985) mengatakan bahwa selain didukung oleh para mahasiswa dan kalangan intelektual lainnya, mingguan Mahasiswa Indonesia juga didukung oleh pihak militer dan pemerintah yang mengajaknya untuk berjuang mencapai tujuan Orde Baru (Raillon, 1985).

Dukungan terhadap lahirnya mingguan ini ditunjukkan dengan menempatan Brigadir Jenderal H. Sugandhi sebagai Penasihat; dan hal itu menunjukan - sekali lagi adanya hubungan yang sangat erat antara Mahasiswa Indonesia dengan rezim baru yang berkuasa; dan tentu saja dengan para mahasiswa Angkatan 1966, yang berhasil menumbangkan Presiden Soekarno dari kekuasaan dan mengusung Jenderal Soeharto untuk memimpin pemerintah Orde Baru, di mana mingguan Mahasiswa Indonesia ini menjadi alat ekspresi dan artikulasi bagi mereka. Banyaknya tokoh Orde Baru yang mendukung lahirnya mingguan ini dan mengharapkan dukungan dari mingguan Mahasiswa Indonesia tidak lain adalah untuk ikut memperkenalkan dan mengkonsolidasikan tujuan-tujuan dari pemerintah Orde Baru itu sendiri (Anwar, 1980; Wibisono, 1980; Raillon, 1985; Gie, 1983 dan 1995; Maxwell, 2001; dan Supriyatna, 2007).

Sementara itu, sosok Rachman Tolleng yang anti Soekarno dan idealismenya untuk melakukan pembaharuan ikut mewarnai 
corak mingguan Mahasiswa Indonesia.

Mingguan ini justru menjadi koran mahasiswa yang dilahirkan oleh mahasiswa, tetapi terbit dan berkembang justru di luar kampus. Dalam hal ini, kembali lagi, Amir Effendi Siregar (1983) mengungkapkan bahwa mingguan Mahasiswa Indonesia adalah salah satu dari koran mahasiswa yang terbit di luar kampus, memerlukan suatu Badan Hukum untuk status hukum, dan memerlukan SIT (Surat Izin Terbit) seperti layaknya "pers umum" ( $c f$ Siregar, 1983; Abrar, 1992; Harahap, 1996; dan Islam, 2006).

Rachman Tolleng, sebagai Pimpinan Redaksi mingguan Mahasiswa Indonesia, juga mengatakan bahwa kelahiran koran ini sebagai alat untuk meruntuhkan pemerintahan Orde Lama (1959-1966). Bahwa para pengasuhnya adalah terdiri dari orang-orang muda, yang pada masa "Demokrasi Terpimpin"-nya Soekarno merasa tertekan aspirasi politiknya, dan ketika peristiwa G-30-S (Gerakan 30 September) tahun 1965 meletus, serta PKI (Partai Komunis Indoensia) mendapat tekanan, merupakan kenyataan yang tak terbantahkan. Orang-orang muda itu umumnya mendapat cap "anak ideologi PSI dan MASYUMI" (Partai Sosialis Indonesia dan Majelis Syuro Muslimin Indonesia), dan telah memanfaatkan momentum ini untuk menyalurkan aspirasi politik mereka dan terlibat aktif bersama TNI-AD (Tentara Nasional Indonesia - Angkatan Darat) untuk meruntuhkan sistem politik Demokrasi Terpimpin-nya Soekarno (Feith, 1964; Ricklefs, 2008; Syafa'at, 2011; Arismunandar, 2012; dan wawancara dengan Rachman Tolleng, 12/3/2001).

Mingguan Mahasiswa Indonesia menjadi koran yang berdiri paling depan dalam kampanye anti Soekarno dari bulan Maret 1966 sampai dengan bulan Juni 1967. Dengan kerangka berfikirnya yang tajam, ilmiah, dan terus terang, mingguan Mahasiswa Indonesia mengkritik berbagai bentuk penyelewengan yang dilakukan oleh pemerintahan Soekarno. Mingguan Mahasiswa Indonesia mengajukan beberapa argumen tentang perlunya menjatuhkan Soekarno. Bagi mingguan ini, Soekarno merupakan sosok yang dianggap sebagai lambang dan penanggung jawab dari suatu tirani yang korup dan sikap pemerintahannya yang tidak kompeten. Serangan terhadap Presiden Soekarno ini dilakukan oleh mingguan Mahasiswa Indoensia melalui tulisan-tulisannya yang dapat dilihat dalam judul berita utama di halaman muka, seperti: "Siapa Dalang GESTAPU? Bung Karno Tidak Dipertjaja lagi sebagai Presiden, Situasi Bandung Setelah Pidato Presiden"; ${ }^{2}$ atau berita utama lain yang berbunyi: "Bung Karno Harus ke MAHMILUB" [Mahkamah Militer Luar Biasa]. ${ }^{3}$

Serangan-serangan terhadap Bung Karno juga dilakukan melalui aksi-aksi Badan Kerjasama Pers dan Kesatuan Aksi. Mahasiswa yang berusaha meruntuhkan kewibawaan dan politik Presiden Soekarno dengan semangat menyerukan: "Tjabut Keputusan MPRS jang Bertentangan dengan UUD 1945". ${ }^{4}$ Bahkan sehari setelah Jenderal Soeharto terpilih sebagai Pejabat Presiden, terpampang dalam halaman muka mingguan Mahasiswa Indonesia, yang berbunyi: "Lantjarkan Pembaharuan di Segala Bidang". 5 Dalam konteks ini, menurut Francois Raillon (1985), selama melakukan kampanye anti Soekarno, peranan mingguan Mahasiswa Indonesia di Bandung sebagai avant-garde Orde Baru semakin harum dan terkenal (Raillon, 1985).

Dalam masa-masa awal konsolidasi pemerintahan Orde Baru, mingguan Mahasiswa Indonesia selain memperhatikan

${ }^{2}$ Berita utama mingguan Mahasiswa Indonesia, No.10. Bandung: Agustus 1966.

${ }^{3}$ Berita utama mingguan Mahasiswa Indonesia, No.14. Bandung: September 1966.

${ }^{4}$ Berita utama mingguan Mahasiswa Indonesia, No.2. Bandung: Djuni 1966.

${ }^{5}$ Berita utama mingguan Mahasiswa Indonesia, No.41. Bandung: Maret 1967. 
pembaharuan politik, juga terus menjalankan fungsinya untuk mengadakan social control. Betapapun mingguan ini mendukung lahirnya pemerintahan Orde Baru di satu sisi, dan berusaha meruntuhkan pemerintahan Orde Lama di sisi lain, namun Mahasiswa Indonesia juga tetap melakukan kontrol sosial, mengawasi elemenelemen yang menyalahgunakan posisi dan kekuasaan mereka, bahkan terhadap mereka yang dianggap tidak kompeten di bidangnya (Albach, 1988; Saidi, 1989; Magenda, 1991; Culla, 1999; dan Aly, 2004).

Mingguan Mahasiswa Indonesia, misalnya, menganggap bahwa parlemen, dalam hal ini DPRS (Dewan Perwakilan Rakyat Sementara), tidak memainkan peranan secara maksimal. Karena itu, mingguan Mahasiswa Indonesia, bersamasama dengan Harian KAMI serta kesatuan aksi lainnya, merasa terpanggil untuk menjadi penyeimbang dari kekuatan pihak TNI-AD dalam pemerintahan. Bahkan mingguan Mahasiswa Indonesia tidak segan-segan untuk mengkritik politik TNIAD; buruknya kinerja BULOG (Badan Urusan Logistik); kelalaian dari para pejabat pemerintah; tender yang didapat perusahaan dengan cara-cara tidak benar; dan sebagainya (Raillon, 1985; Azziz, 2006; dan Anggraeni, Suwirta \& Sarimaya, 2016).

Perjalanan sejarah mingguan Mahasiswa Indonesia, dengan demikian, sangat erat kaitannya dengan sejarah kelahiran pemerintahan Orde Baru. Pada awalnya, mingguan ini merupakan suara dari para aktivis, dan bahkan ekstrimis, bagi Orde Baru yang menghendaki satu perubahan yang cepat dan radikal. Beberapa tahun kemudian, ternyata pemerintah Orde Baru sendiri menjadi bagian dari establishment politik yang sering dikritik oleh mingguan Mahasiswa Indonesia. Sejalan dengan itu, terjadi juga perubahan dari mingguan ini, yakni dari memberikan dukungan penuh dan tanpa syarat kepada pihak penguasa yang baru menjadi dukungan dengan disertai kritik-kritik sosial yang tajam kepada pemerintah Orde Baru (Siregar, 1983; Raillon, 1985; dan Arismunandar, 2012).

Dalam tahun 1971-1972, misalnya, mingguan Mahasiswa Indonesia telah berubah dari koran yang penuh emosi kepada koran yang bijaksana; dan hal ini seakan-akan mengesankan bahwa daya kritis mingguan Mahasiswa Indonesia yang terkenal keras sudah mulai mati. Hal ini terjadi setelah pemerintah Orde Baru mendapatkan legitimasinya melalui kemenangan dalam PEMILU (Pemilihan Umum) tahun 1971. Namun pada tahun 1972-1974, mingguan Mahasiswa Indonesia mulai merasakan adanya ketidakcocokan dengan kepentingan politik pemerintah Orde Baru. Mingguan ini melihat banyak ketidakberesan dengan kinerja politik pemerintah Orde Baru. Pada periode ini justru merupakan era baru bagi mingguan Mahasiswa Indonesia untuk hadir kembali dengan sifat kritisnya yang terkenal (Siregar, 1983; Raillon, 1985; Arismunandar, 2012; dan Novianto, 2016).

Sejalan dengan sejarah keberadaan Mahasiswa Indonesia ini, Francois Raillon (1985) membagi tiga tahapan perkembangan, yaitu secara politik, ideologi, dan kritik. Secara politik, mingguan Mahasiswa Indonesia yang membawa amanat dan semangat Angkatan 1966 telah menjadi salah satu pihak yang ikut mengupayakan turunnya pemerintahan Soekarno melalui perjuangan yang berat dengan menyajikan slogan-slogan, beritaberita, dan opini-opini yang tertuang dalam goresan pena para mahasiswa dan golongan intelektual, sehingga membawa pengaruh terhadap banyak kalangan di masyarakat. Secara ideologis, mingguan Mahasiswa Indonesia banyak memberikan sumbangan terhadap tegaknya ideologi Orde Baru. Hampir lebih dari 400 terbitan dalam jangka waktu hidupnya, mingguan Mahasiswa Indonesia secara teratur mengemukakan gagasan-gagasan yang 
pada intinya berkenaan dengan harapanharapan akan datangnya modernisasi dan pembangunan di Indonensia. Dengan demikian, baik secara langsung ataupun tidak langsung, mingguan Mahasiswa Indonesia telah memudahkan usaha pemerintah Orde Baru untuk menemukan keabsahan dari ideologinya dan upaya untuk memasyarakatkannya. Dan secara kritik, mingguan Mahasiswa Indonesia tetap menjalankan fungsi kontrol sosial terhadap jalannya pemerintahan Orde Baru, terutama terhadap hambatan-hambatan yang dianggap mengganggu pembangunan dan modernisasi di Indonesia ( $c f$ Siregar, 1983; Raillon, 1985; dan Arismunandar, 2012).

\section{Kritik Sosial Mingguan "Mahasiswa Indonesia" terhadap Masalah KKN (Korupsi, Kolusi, dan Nepotisme) pada Masa Awal Orde Baru. Mingguan} Mahasiswa Indonesia lahir sejalan dengan bangkitnya pemerintahan Orde Baru. Bahwa mingguan ini banyak berperan dalam upaya mengkonsolidasikan pemerintahan Orde Baru, bahkan ikut membentuk ideologi pemerintahan baru, jelas tak terbantahkan lagi (Siregar, 1983; Raillon, 1985; Arismunandar, 2012; dan Novianto, 2016). Namun seiring dengan perkembangan zaman, terutama semenjak tahun 1972, mingguan Mahasiswa Indonesia kembali menjadi pers yang tajam dalam mengungkap berbagai ketidakberesan dalam tubuh pemerintahan Orde Baru. Berbagai praktek KKN dari pihak-pihak yang dekat dengan Presiden Soeharto telah menjadi sorotan utama dalam kritik-kritik sosial yang dilakukan oleh mingguan Mahasiswa Indonesia dalam tahun-tahun terakhir menjelang "kematiannya" pada tahun 1974 (Siregar, 1983; Raillon, 1985; Junaedhie, 1991; Hill, 2011; dan Arismunandar, 2012).

Ada beberapa hal yang ingin jadikan bahan kajian dalam mengungkap sorotan mingguan Mahasiswa Indonesia di Bandung dalam melontarkan kritik-kritik sosialnya terhadap berbagai praktek KKN pada masa awal Orde Baru, seperti berikut ini:

\section{Pertama, Seputar Pembentukan}

Asisten Pribadi Presiden. Seperti yang sudah dijelaskan sebelumnya bahwa semenjak awal dalam pemerintah Orde Baru terlihat adanya dualisme, yakni di satu sisi Presiden Soeharto mempercayakan kepada para pembantu resminya di kabinet, sedangkan di sisi lain ia juga lebih bertumpu pada SPRI (Staf Pribadi) yang terdiri dari para perwira TNI-AD (Tentara Nasional Indonesia - Angkatan Darat) yang dekat dengan Presiden Soeharto. Dalam hal menjalankan kepemimpinannya, Presiden Soeharto memang sangat bergantung kepada kelompok kecil para penasihat pribadinya, yang diangkat dari kalangan TNI-AD. Pada tahun 1966, misalnya, Presiden Soeharto membentuk SPRI yang terdiri dari para perwira tinggi TNI-AD. Di bawah pimpinan Mayor Jenderal Alamsyah Ratuperwiranegara, anggota SPRI ini dibagi dalam urusan yang berbeda-beda, seperti: urusan keuangan; politik; intelejen dalam dan luar negeri; kesejahteraan sosial; pemilihan umum; bahkan urusan umum dan khusus lainnya (Vatikiotis, 1998; Crouch, 1999; Ricklefs, 2008; Jenkins, 2010; dan Rahmat, 2011).

Dalam hal ini mingguan Mahasiswa Indonesia, bersama-sama dengan para mahasiswa dan kalangan pers lainnya, melakukan kritik-kritik sosial karena kesal terhadap keberadaan dan peranan SPRI. Lembaga SPRI ini, dalam pandangan mingguan Mahasiswa Indonesia, seperti layaknya sebuah "kabinet bayangan" yang lebih riil berkuasa daripada kabinet pembangunan yang resmi. Akibat dari banyaknya kritik sosial yang dilontarkan kepada SPRI, maka lembaga ini sempat dibubarkan bersamaan dengan pengangkatan kabinet baru pada tahun 1968. Namun, dalam perkembangan selanjutnya, pengaruh dari kalangan orang-orang SPRI ini tetap ada. Hal itu terbukti bahwa pada bulan Februari 1968, Mayor Jenderal Alamsyah 
Ratuperwiranegara diangkat sebagai Sekertaris Negara, yang membawahi staf Presiden. Sedangkan Yoga Sugama, yang dulu menjabat sebagai perwira SPRI urusan intelejen dalam negeri, diangkat menjadi Kepala BAKIN (Badan Koordinasi Intelejen Negara). Selanjutnya Jenderal Surjo, Sudjono Humardani, dan Ali Moertopo diangkat menjadi ASPRI (Asisten Pribadi) untuk diperbantukan kepada Presiden Soeharto (Siregar, 1983; Raillon, 1985; Ricklefs, 2008; Jenkins, 2010; Hill, 2011; Rahmat, 2011; dan Arismunandar, 2012).

Dengan adanya asisten-asisten pribadi Presiden seperti itu, maka semakin membuka lebar hubungan bisnis antara para pejabat ASPRI dengan para pengusaha Cina dan orang-orang Jepang. Dan para "Jenderal Politik dan Uang" ini, tidak pelak lagi, menjadi bulan-bulanan kritik sosial yang tajam dari berbagai pihak, termasuk dari mingguan Mahasiswa Indonesia di Bandung (Raillon, 1985; Crouch, 1999; Ricklefs, 2008; dan Rahmat, 2011).

\section{Kedua, Kegagalan Kinerja BULOG}

(Badan Urusan Logistik). Sekitar tahun 1970-an, hasil-hasil pembangunan ekonomi pertama pada masa awal Orde Baru menunjukan adanya pertumbuhan ekonomi yang semakin membaik, meskipun hal pokok yang ingin dicapai oleh para pembaharu ekonomi pada masa Orde Baru itu belum terwujud sepenuhnya. Dengan perkataan lain, adanya ketidakseimbangan pembangunan ekonomi yang terjadi pada masa Orde Lama, dan ingin diperbaharui oleh pemerintah Orde Baru, justru belum dapat dicapai dengan baik (Raillon, 1985; Anggraeni, Suwirta \& Sarimaya, 2016; Nasution, 2016; dan Saragih, 2016).

Dalam hal ini, mingguan Mahasiswa Indonesia banyak mengupas kritikankritikan di seputar kehidupan sosial dan ekonomi masyarakat kepada pemerintah Orde Baru, terutama di sekitar pertumbuhan ekonomi yang masih tidak seimbang tersebut. Di samping itu, masalah pembangunan yang masih terpusat di pulau Jawa dengan mengabaikan kondisi pulaupulau di luar Jawa; tekanan penduduk pulau Jawa yang semakin meledak; dan lain-lainnya menjadi sorotan mingguan Mahasiswa Indonesia. Mingguan ini, misalnya, menyoroti masalah penyelundupan, seperti tergambar dalam Mahasiswa Indonesia, No.52 (Juni) 1967, dengan menurunkan tulisan Naswil Idris yang berjudul, "Penjelundup dari Riau ke Singapura: Jang Ketjil Tertangkap, jang Besar ke Mana?"' (Idris, 1967). Begitu juga dengan masalah transmigrasi, yang disorot oleh mingguan Mahasiswa Indonesia, pada tahun 1972, dengan menurunkan tulisan yang berjudul, "Transmigrasi, Aduh Pelik". ${ }^{6}$

Masalah utama yang juga disinggung oleh mingguan Mahasiswa Indonesia adalah di sekitar pendistribusian beras. Dalam hal ini, mingguan Mahasiswa Indonesia banyak menyoroti kinerja BULOG, badan yang ditunjuk oleh pemerintah Orde Baru untuk mengontrol jalannya perdagangan beras dan menjamin pengadaan pangan secara nasional. BULOG ini pertama kali dibentuk oleh pemerintahan Orde Baru pada tahun 1966. Badan ini mula-mula dibentuk dengan tugas utama untuk memberi beras kepada pegawai negeri, yang sebagian gajinya diberikan dalam bentuk bahan pangan (Raillon, 1985; Ali et al., 1986; Ashari, 2015; Anggraeni, Suwirta \& Sarimaya, 2016; Nasution, 2016; dan Saragih, 2016).

Setelah keluar Keputusan Presiden No.11 tahun 1969, BULOG dijadikan alat untuk menstabilkan harga bahan pangan serta bertanggung jawab dalam berbagai bidang usaha yang sangat menguntungkan - antara lain dalam pendistribusian beras, pengimpor tunggal gula, gandum, dan lain-lain. BULOG akhirnya juga diberi wewenang untuk mengelola administrasi bantuan dana dari luar negeri. Dalam perkembangan

${ }^{6}$ Lihat mingguan Mahasiswa Indonesia, No.308. Bandung: Mei 1972. 
selanjutnya, BULOG memegang monopoli dalam dunia usaha yang berkaitan dengan bahan pangan di Indonesia (Ali et al., 1986; Mas'oed, 1989; Ashari, 2015; Nasution, 2016; dan Saragih, 2016).

Menurut Harold Crouch (1999), pengamat politik tentara Indonesia dari Australia, BULOG dari segi politik bisa digambarkan sebagai "Komando Logistik Nasional", yang dikuasai oleh perwiraperwira TNI-AD (Tentara Nasional Indonesia - Angkatan Darat) untuk mengurusi masalah pembagian gaji dalam bentuk beras bagi para pegawai negeri. BULOG lalu berkembang di bawah pimpinan Letnan Jenderal Achmad Tirto Sudiro, seorang perwira senior yang lama berkarier di bidang keuangan dan logistik tentara (Crouch, 1999).

BULOG juga menjadi salah satu badan penting bagi TNI-AD untuk mencari dana, di samping masukan dana dari perusahaan minyak milik negara, yaitu PERTAMINA (Perusahaan Tambang Minyak Nasional). Pencarian dana ini tidak lain dalam rangka menutupi kekurangan anggaran yang disediakan oleh pemerintah. Bahwa dengan adanya BULOG ini telah sangat berhasil membuka kesempatan-kesempatan meningkatkan dana bagi TNI-AD, baik secara lembaga maupun bagi para perwira tentara secara perseorangan (Ali et al., 1986; Samego et al., 1998; Singh, 1999; Jenkins, 2010; Permana, 2012; Basuki, 2014; dan Ashari, 2015).

Dengan keleluasaan monopoli dalam dunia usaha di bidang bahan pangan, BULOG telah berhasil mengembangkan kerjasama dengan beberapa perusahaan swasta yang bergerak tidak hanya dalam bidang perdagangan bahan pangan, tetapi juga di bidang usaha lainnya yang sangat menguntungkan. Dalam hal ini, hubungan antara para pejabat BULOG dengan para pengusaha dari luar negeri, terutama dengan pengusaha Cina yang diberi peluang untuk memasok bahan pangan ke dalam negeri, walaupun sebenarnya bahan pangan tersebut tersedia di dalam negeri. Hal ini dikarenakan adanya tawaran komisi yang disediakan oleh para pengusaha Cina itu kepada para pejabat BULOG memang sangat menggiurkan. Di sinilah praktek KKN (Korupsi, Kolusi, dan Nepotisme) mulai menjadi sorotan pada masa awal Orde Baru (Ali et al., 1986; Crouch, 1999; Ashari, 2015; Nasution, 2016; dan Saragih, 2016).

Mingguan Mahasiswa Indonesia di Bandung, dengan artikelnya yang berjudul: "BULOG: Peranannja Perlu Ditindjau", mengkritik habis-habisan tentang BULOG yang tidak melakukan peranannya dengan baik, malah menghambat laju perdagangan beras rakyat. Mingguan Mahasiswa Indonesia ini, antara lain, menyatakan sebagai berikut:

BULOG membeli beras tanpa kenal waktu dan tanpa melihat "angin". Seringkali terdjadi ia memborong beras dari petani dan pasaran di musim patjeklik, di saat beras kurang di pasaran. Tidak ajal lagi, harga beras melondjak seperti misalnja pada tahun 1967 dan awal tahun 1968. Sebaliknja, di saat harga beras sangat rendah, BULOG tidak berhenti membagi-bagikan beras konsumsi kepada pegawai negeri dan ABRI. Maka semakin merosotlah harga beras, membuat petani di mana-mana mendjerit.

Tetapi alangkah tragisnja apa jang terdjadi kala itu! Di tengah-tengah djeritan para produsen beras, karena tidak bisa mendjual kelebihan beras mereka (kuartal 19671968), BULOG malah tidak henti-hentinja mendatangkan beras. Pada tanggal 14 April 1969, misalnja, dari Korea tiba 113.000 x 80 $\mathrm{kg}$ beras kelas menengah dengan harga tinggi. Padahal waktu itu di dalam negeri banjak kelebihan beras jang bisa dibeli dengan harga murah dan dengan mutu jang baik pula. ${ }^{7}$

Kritikan dari mingguan Mahasiswa Indonesia ini sangat tajam. Ia melihat bahwa dalam kenyataannya, BULOG (Badan Urusan Logistik) tidak dapat melaksanakan

${ }^{7}$ Lihat mingguan Mahasiswa Indonesia, No.160. Bandung: Djuli 1969. 
tugasnya dengan baik, malah sebaliknya BULOG banyak menghambat jalannya mekanisme perdangan beras yang sehat dan merugikan para petani dan produsen beras lokal. Mingguan Mahasiswa Indonesia juga melihat bahwa yang seringkali dilakukan oleh BULOG adalah spekulasi pasar untuk kepentingan para pejabat BULOG sendiri. Padahal, menurut mingguan Mahasiswa Indonesia, dalam operasi-operasinya BULOG itu dibiayai dengan kredit oleh Bank Indonesia dan tidak masuk dalam APBN (Anggaran Pendapatan dan Belanja Negara) serta mendapat jaminan dari Departemen Keuangan (cf Ali et al., 1986; Mas'oed, 1989; Ashari, 2015; dan ibidem dengan catatan kaki 7).

Dalam operasi kerjanya, BULOG memang diberikan tugas untuk mengumpulkan persediaan bahan pangan secara nasional agar mampu menstabilkan harga-harga, baik dari produsen maupun konsumen. Namun dalam prakteknya, BULOG banyak sekali melakukan operasioperasi pasar yang justru membuat tidak seimbang harga-harga bahan pangan nasional di dalam negeri. Spekulasi yang dilakukan oleh BULOG, dengan mengambil dana untuk pembelian beras dari luar negeri, kerap kali terjadi (Ali et al., 1986; Crouch, 1999; Ashari, 2015; Nasution, 2016; dan Saragih, 2016).

Data-data dari para pengamat menunjukan, misalnya, ketika BULOG mendapat kredit dari BI (Bank Indonesia) tahun 1968, dengan suku bunga 3\%, BULOG malah menyimpan sebagian dana dari pemerintah itu di bank-bank swasta secara tidak sah dan menawarkan bunga antara $10-15 \%$ demi melakukan spekulasi pasar; atau sebagian dana itu diinvestasikan pada proyek-proyek jangka pendek. Dalam hal ini BULOG memberikan pinjaman sebagian dana itu kepada Bank Dharma Ekonomi, cabang perusahaan yang dikuasai oleh TNI-AD (Tentara Nasional Indonesia - Angkatan Darat). Begitu juga dengan PT
BERDIKARI (Perseroan Terbatas Berdiri Diatas Kaki Sendiri), yang mendapatkan kucuran dana dari BULOG. Bahkan, dana dari BULOG juga disimpan di Bank Sumatra, yang direkturnya adalah seorang perwira menengah TNI-AD. Akibatnya adalah bahwa para pejabat BULOG enggan untuk mengadakan pembelian beras di awalawal panen, dengan alasan akan jauh lebih menguntungkan apabila dana-dana tersebut disimpan selama mungkin di sektor lain (Ali et al., 1986; Samego et al., 1998; Crouch, 1999; Singh, 1999; Jenkins, 2010; dan Ashari, 2015).

Dalam hal ini, Harold Crouch (1999) menjelaskan lebih lanjut, sebagai berikut:

\begin{abstract}
Pada tahun 1967, BULOG menangguhkan pembelian beras pada masa panen utama dalam setengah tahun pertama, dengan maksud mengadakan pembelian besar-besaran pada masa panen kering di pertengahan tahun. Tetapi panen tengah tahun itu sangat sedikit, sehingga sampai Oktober 1967, BULOG hanya bisa membeli 280.000 ton saja, dibanding dengan target pembelian yang 567.000 ton. Sehingga, akibatnya BULOG tidak mempunyai persediaan yang cukup pada waktu harga-harga bahan pangan itu naik pada akhir tahun 1967-1968 (Crouch, 1999:314).
\end{abstract}

Dalam kritik-kritik sosialnya, mingguan Mahasiswa Indonesia di Bandung kemudian mengingatkan kembali tentang fungsi dan peranan BULOG (Badan Urusan Logistik). Mingguan ini memberikan dua alternatif jalan keluar bagi situasi yang dihadapi oleh BULOG, yaitu: (1) BULOG harus melakukan tindakan yang bersifat konjungtural, yaitu supaya impor dan distribusi beras dihentikan ketika harga sedang turun; dan (2) BULOG harus melakukan tindakan yang bersifat struktural, yaitu menata kembali peranannya yang tidak hanya sebagai menyalur beras bagi pegawai negeri tetapi juga sebagai pengatur beras atau buffer stock secara nasional. Mengenai prinsip buffer stock yang harus dimainkan oleh BULOG ini, mingguan Mahasiswa 
Indonesia menjelaskan secara sederhana, sebagai berikut:

Bila harga terlalu tinggi, BULOG harus mendrop beras dalam djumlah jang tepat untuk mempertahankan tingkat harga jang dianggap lajak (misalnja pada masa patjeklik); dan sebaliknja, BULOG harus memberikan semua kelebihan jang di pasaran pada saat harga beras terlalu rendah demi mempertahankan harga jang lajak tadi. ${ }^{8}$

Apabila pada tahun 1969, kegagalan BULOG (Badan Urusan Logistik) dalam pengadaan beras itu dapat dikompensasikan dengan keberhasilannya dalam peningkatan dana tersebut, namun pada tahun 1970an, dengan adanya pengembangan dari sumber-sumber dana alternatif bagi TNI-AD (Tentara Nasional Indonesia Angkatan Darat), pemerintah Orde Baru semakin memperlihatkan keprihatinan terhadap ketidakberhasilan BULOG dalam menstabilkan harga-harga kebutuhan pokok (Ali et al., 1986; Crouch, 1999; Ashari, 2015; Nasution, 2016; dan Saragih, 2016). Hal ini, secara politis, jelas merupakan masalah yang sensitif. Dalam hal ini, Letnan Jenderal Achmad Tirto Sudiro, sebagai Kepala BULOG, sering mendapatkan kritikan dari mingguan Mahasiswa Indonesia di Bandung, karena ketidaksanggupannya dalam menyediakan beras yang cukup di pasaran. Mingguan Mahasiswa Indonesia juga melihat adanya penjualan paksa dari para petani, dan BULOG gagal dalam memperhitungkan kebutuhan beras impor (Ali et al., 1986; Mas'oed, 1989; Ashari, 2015; dan ibidem dengan catatan kaki 8).

Berbagai tuduhan yang tidak mengenakan dari mingguan Mahasiswa Indonesia terhadap Kepala BULOG, serta dukungan mingguan ini terhadap "Gerakan Anti Lapar" dari para mahasiswa,

${ }^{8}$ Lihat kembali, misalnya, berita utama "BULOG: Peranannja Perlu Ditindjau" dalam mingguan Mahasiswa Indonesia, No.160. Bandung: Djuli 1969. semakin membulatkan tekad mingguan Mahasiswa Indonesia untuk meminta supaya Letan Jenderal Achmad Tirto Sudiro segera mundur dari jabatannya (Raillon, 1985; Ali et al., 1986; dan Ashari, 2015). Bersamaan dengan itu, mingguan Mahasiswa Indonesia malah memuji usaha Menteri Widjojo Nitisastro, seorang teknokrat dari UI (Universitas Indonesia) Jakarta, dalam mengatasi masalah kekurangan beras. Bahkan ketika B.M. (Burhanuddin Muhammad) Diah, pemimpin harian Merdeka di Jakarta dan dipandang sebagai salah seorang pendukung Ali Moertopo, menyebarkan berita bahwa Widjojo Nitisastro sebagai dalang demonstrasi anti TMII (Taman Mini Indonesia Indah), mingguan Mahasiswa Indonesia, No.339, edisi Desember 1972, segera mengangkat Widjojo Nitisastro sebagai Man of the Year 1972. ${ }^{9}$

Pada tahun 1972, ketika BULOG tidak memiliki cukup persediaan bahan pangan dan harga-harga bahan pokok membumbung tinggi, maka mengakibatkan inflasi melonjak dan timbul ketidakpuasan mahasiswa di beberapa kota besar di Indonesia. Pemerintah Orde Baru merasa khawatir dengan fenomena ini, yang dinilai akan melemahkan keberhasilan pembangunan ekonomi secara nasional. Akhirnya, keinginan mingguan Mahasiswa Indonesia di Bandung agar Letnan Jenderal Achmad Tirto Sudiro mundur dari jabatannya tercapai, seiring dengan krisis ekonomi pada tahun 1972-1973. Letnan

\footnotetext{
${ }^{9}$ Lihat "Widjojo Nitisastro: Man of the Year 1972" dalam mingguan Mahasiswa Indonesia, No.339. Bandung: Desember 1972. Lihat juga, misalnya, studi yang dilakukan oleh Nindarsari (1984); Francois Raillon (1985); Anwar Nasution (1985); Kurniawan Junaedhie (1991); Akhmad Zaini Abar (1995); David T. Hill (2011); dan Muhdar (2012) dalam konteks persaingan elite politik pada masa-masa awal Orde Baru antara kelompok yang pro Widjojo Nitisastro dengan yang pro Letnan Jenderal Ali Moertopo dalam strategi pembangunan ekonomi di Indonesia; atau antara kelompok yang pro PWI (Persatuan Wartawan Indonesia) pimpinan B.M. Diah yang didukung oleh pemerintah Orde Baru dengan PWI pimpinan Rosihan Anwar, yang dinilai penganut ideologi Sosialis dan bersikap kritis kepada pemerintah Orde Baru.
} 
Jenderal Achmad Tirto Sudiro kemudian diberhentikan dari jabatannya sebagai Kepala BULOG; dan ia diangkat menjadi Duta Besar Indonesia untuk Jerman Barat dengan pertimbangan jasa-jasanya di masa lalu (Ali et al., 1986; Soeharto, 1989; Elson, 2001; Ashari, 2015; Nasution, 2016; dan Saragih, 2016).

\section{Ketiga, Pembangunan TMII (Taman Mini Indonesia Indah) pada Tahun}

1972. Rencana pembangunan TMII, yang diprakarsai oleh Ibu Negara, Tien Soeharto, pada tahun 1972 , ternyata mengundang banyak kontroversi, terutama dari kalangan pers dan mahasiswa yang peduli terhadap masalah sosial-ekonomi masyarakat. Pembangunan TMII, yang merupakan kompleks hiburan dan kebudayaan, membutuhkan biaya yang sangat besar dan berusaha mencari dana dari kalangan instansi-instansi penting untuk memberikan sumbangan dana secara sukarela. Sedangkan di sisi lain, Presiden Soeharto sendiri, sebagai pimpinan nasional, baru saja mengeluarkan kebijakan untuk hidup sederhana; mengurangi pengeluaran dana yang tidak perlu; dan agar mencurahkan perhatian pada usaha pembangunan nasional yang konstruktif (Soeharto, 1989; Poesponegoro \& Notosusanto eds., 1991; Siregar, 1994; Elson, 2001; Ricklefs, 2008; dan Novianto, 2016).

Tentu saja, inisiatif pembangunan TMII dari Ibu Tien Soeharto dianggap tidak tepat untuk diwujudkan pada masa itu, mengingat proyek tersebut belum begitu dibutuhkan oleh masyarakat Indonesia. Apalagi pada sekitar tahun 1972 itu perekonomian Indonesia sedang jatuh, akibat kekacauan distribusi beras yang dilakukan oleh BULOG (Badan Urusan Logistik). Dari kalangan mahasiswa sendiri muncul berbagai gerakan untuk memprotes proyek pembangunan TMII ini. Gerakan-gerakan yang dimunculkan oleh para mahasiswa itu menamakan dirinya: "Gerakan Penghematan"; "Gerakan Akal Sehat"; dan "Gerakan Penyelamat Uang
Rakyat" (Magenda, 1991; Siregar, 1994; Culla, 1999; Elson, 2001; Aly, 2004; dan Anto \& Sirait, 2011).

Dalam hal ini, mingguan Mahasiswa Indonesia di Bandung juga ikut bergabung dan mendukung gerakan-gerakan yang dilakukan oleh para mahasiswa tersebut. Dalam editorialnya yang berjudul "Keprihatinan dalam Pembangunan", mingguan Mahasiswa Indonesia, No.290 (Djanuari) 1972, melakukan kritik yang tajam sebagai berikut:

Akibat dari terbatasnja kekajaan masjarakat itu adalah bahwa kita diharuskan menghemat setiap dana jang ada. Setiap kekajaan itu dibuat seproduktif mungkin sehingga dapat diambil manfaat jang sebesar-besarnja bagi kepentingan masjarakat luas. Prinsip ini berlaku bagi setiap dana dari manapun sumbernja, apakah itu milik negara, bantuan atau investasi asing, tak terketjuali modal domestik maupun milik pribadi.

[...] kalau kepada rakjat kita mengandjurkan untuk menekan kosumsinja - jang sudah di bawah ukuran jang lajak itu - untuk ditabungkan, maka tidak sepantasnja apabila masih ada projek pembangunan jang bersifat mertjusuar, dengan biaja non-budgetair sekalipun. ${ }^{10}$

Walaupun mingguan Mahasiswa Indonesia di Bandung, dalam editorialnya itu, tidak mencantumkan dengan jelas dan menunjuk pada proyek pembangunan TMII (Taman Mini Indonesia Indah) di Jakarta, namun setidaknya pada saat itu pembaca akan dengan sangat jelas menebak kepada siapa mingguan ini melontarkan kritikannya. Berbagai sindiran juga dilontarkan terhadap rencana pembangunan TMII ini. Bahkan dalam pandangan Jenderal Soemitro sendiri, sebagai PANGKOPSKAMTIB (Panglima Komando Operasi Keamanan dan Ketertiban) yang nampaknya sedang berseteru dengan orang-orang SPRI (Staf Pribadi)-nya Presiden Soeharto,

\footnotetext{
${ }^{10}$ Lihat tajuk rencana "Keprihatinan dalam Pembangunan" dalam mingguan Mahasiswa Indonesia, No.290. Bandung: Djanuari 1972.
} 
proyek TMII ini dianggap tidak tepat dan bertentangan dengan kepentingan negara mengingat biayanya yang terlampau mahal dan tidak jelas cara memperoleh dananya (Soeharto, 1989; Magenda, 1991; Siregar, 1994; Cahyono, 1998; Culla, 1999; Elson, 2001; dan Aly, 2004).

Disebut-sebut, misalnya, bahwa biaya proyek pembangunan TMII itu mencapai Rp. 10,5 milyar. Proyek TMII ini, dengan demikian, dianggap terlalu dini dicanangkan sehingga tidak ada bedanya, meminjam istilah dari para aktivis mahasiswa, dengan "proyek mercusuar zaman NASAKOM (Nasional, Agama dan Komunis)-nya Presiden Soekarno dahulu" (dalam Anwar, 1980; Raillon, 1985; dan Gie, 1995). Ada juga informasi bahwa ibu Tien Soeharto memungut fee sebesar $10 \%$ dari tendertender proyek pembangunan yang disetujui oleh pemerintah; atau dari sumbangansumbangan dana pengusaha, umumnya dari para pengusaha China, untuk pembangunan TMII di Jakarta. Apa yang dilakukan oleh ibu Tien Soeharto, sebagai Madam Tien President, disindir oleh para mahasiswa dan pihak-pihak yang kritis terhadap pemerintah Orde Baru sebagai Madam Ten Procent (Aly, 2004; Abdulgani-Knapp, 2007; Jenkins, 2010; dan Taufik, 2014).

Memang, proyek pembangunan TMII mempunyai tiga aspek penting, yaitu: (1) isu proyek TMII telah mengundang sikap kritis dan populis serta keberanian pers dalam mengemukakan suara-suara keprihatinan dari masyarakat; (2) proyek TMII telah melahirkan kembali aksi-aksi protes mahasiswa setelah isu korupsi tahun 1970-an terhenti untuk sementara; dan (3) isu proyek TMII juga telah memancing konflik antara negara dan masyarakat, di mana reaksi negara semakin keras dan represif terhadap para pemrotesnya (Aly, 2004; AbdulganiKnapp, 2007; dan Raditya, 2018).

Bahkan menurut Francois Raillon (1985), aksi protes dalam isu proyek TMII ini sudah mengarah kepada gerakan radikalisme mahasiswa. Dan mingguan Mahasiswa Indonesia di Bandung menjadi salah satu media yang memberi semangat dalam melakukan kritik-kritik sosial dan aksi protes mahasiswa kepada pemerintah Orde Baru (Raillon, 1985). Aksi-aksi protes ini, bersamaan dengan akumulasi kekecewaan lainnya, akan menjadi pemicu bagi lahirnya gerakan mahasiswa yang lebih massif dan radikal, yaitu peristiwa MALARI (Malapetaka 15 Januari) tahun 1974, dimana mingguan Mahasiswa Indonesia di Bandung terkena imbasnya, yakni ditutup dan mati untuk selama-lamanya (Siregar, 1983; Raillon, 1985; Cahyono, 1998; Aly, 2004; dan Yogaswara, 2009).

\section{Reaksi Pemerintah Orde Baru terhadap Mingguan "Mahasiswa Indonesia" di \\ Bandung. Pada tahun-tahun awal berdirinya} Orde Baru, mingguan Mahasiswa Indonesia tampil menjadi salah satu penegak bagi munculnya pemerintah yang baru ini. Mingguan Mahasiswa Indonesia juga, sebagaimana dinyatakan oleh Francois Raillon (1985), menjadi “propagandis yang paling giat dalam membela kepentingan politik dan ideologi Orde Baru di Indoensia" (Raillon, 1985). Pada masa itu, kehidupan pers memang mengalami perkembangan yang pesat setelah sekian lama, terutama pada masa Orde Lama (1959-1965), terpasung dan tidak memiliki kebebasan yang berarti (Lee, 1971; Smith, 1986; Surjomihardjo et al., 2002; dan Suwirta, 2008).

Mingguan Mahasiswa Indonesia, yang muncul beberapa bulan setelah tahun 1965 dan dilahirkan oleh mereka yang menamakan dirinya Angkatan 1966, menjadi koran satu-satunya di Jawa Barat yang berani mendobrak pemerintah Orde Lama di bawah kepemimpinan Presiden Soekarno. Padahal pada masa itu korankoran lainnya di Jawa Barat lebih senang bersikap berdiam diri. Mingguan Mahasiswa Indonesia, sekali lagi, giat dalam ikut menjatuhkan Presiden Soekarno di satu sisi, dan di sisi lain turut membantu TNI-AD 
(Tentara Nasional Indonesia - Angkatan Darat) dalam membersihkan sisa-sisa PKI (Partai Komunis Indonesia) dengan berbagai tulisannya yang kritis, tajam, dinamis, dan segar (cf Wibisono, 1980; Siregar, 1983; Raillon, 1985; Abar, 1995; dan Hill, 2011).

Hal tersebut tentu saja sangat membantu konsolidasi kekuasaan pemerintah Orde Baru, terutama mengenai kinerja dan citra tentara yang sedang mencari kekuasaan. Maka tidaklah heran kalau mingguan Mahasiswa Indonesia pun sangat dekat dan didukung oleh tentara di Jawa Barat (Divisi Siliwangi) dan oleh beberapa elite politik Orde Baru lainnya. Hal itu terlihat dari bantuan-bantuan yang diberikan oleh tentara Siliwangi, terutama PANGDAM (Panglima Daerah Militer) H.R. (Hartono Rekso) Dharsono, dengan menyedian kertas misalnya. Kedekatan yang terbina baik antara tentara Siliwangi dengan mingguan Mahasiswa Indonesia juga nampak bahwa kantor redaksi Mahasiswa Indonesia yang di Jalan Tamblong No.1 Bandung selalu kedatangan tamu-tamu tentara, khususnya dari Siliwangi. Tidak hanya itu, para elite politik Orde Baru, ataupun para intelektual dari Bandung dan Jakarta, juga sering mengunjungi kantor redaksi mingguan Mahasiswa Indonesia di Bandung (Siregar, 1983; Raillon, 1985; dan wawancara dengan Rachman Tolleng, 12/3/2001).

Prinsip partnership antara pemerintah Orde Baru, TNI-AD, dan mingguan Mahasiswa Indonesia, untuk sementara waktu, dapat terbina dengan baik. Pemerintah Orde Baru sangat diuntungkan oleh kehadiran mingguan Mahasiswa Indonesia, karena turut membantu tidak hanya dalam menjatuhkan dan "membersihkan" sisa-sisa kekuatan politik Orde Lama dan upaya mempropagandakan pemerintahan Orde Baru, tetapi juga karena turut membantu pemerintah yang baru dalam mengarahkan pembentukan ideologinya yang "pembangunan sentris" (Wibisono, 1980; Siregar, 1983; Raillon,
1985; Sundhaussen, 1987; Crouch, 1999; Singh, 1999; dan Novianto, 2016). Gagasan-gagasan seperti "modernisasi dan pembangunan" menjadi menu utama dari mingguan Mahasiswa Indonesia, yang disajikan setiap saat kepada masyarakat luas.

Sejalan dengan bergulirnya waktu, pada akhir tahun 1967, mingguan Mahasiswa Indonesia menemukan ada yang salah dalam elemen birokrasi dan pemerintahan Orde Baru. Praktek KKN (Korupsi, Kolusi dan Nepotisme) kerap kali terjadi dalam tubuh pemerintah Orde Baru. Hal itu menjadikan mingguan Mahasiswa Indonesia berada dalam posisi yang serba salah. Namun, hal ini tidak membuat mingguan Mahasiswa Indonesia kehilangan daya kritisnya. Tulisan-tulisan dalam mingguan Mahasiswa Indonesia yang bersifat kreatif, dinamis, dan segar tetap saja dilontarkan (Siregar, 1983; Raillon, 1985; Junaedhie, 1991; Surjomihardjo et al., 2002; dan Aly, 2004). Bahkan tidak segan-segan, mingguan ini melontarkan tuduhan tentang adanya korupsi yang dilakukan oleh para perwira TNI-AD yang dekat dengan Presiden Soeharto, seperti: Ibnu Sutowo, Alamsyah Ratuperwiranegara, Suryo, Achmad Tirto Sudiro, Sudjono Humardani, Ali Moertopo, dan sebagainya (Siregar, 1983; Raillon, 1985; Sundhaussen, 1987; Soeharto, 1989; Cahyono, 1998; Crouch, 1999; Elson, 2001; dan Jenkins, 2010).

Pemerintah Orde Baru, dalam hal ini Presiden Soeharto, pada mulanya menyikapi berbagai tuduhan korupsi dari para perwira TNI-AD, terutama perwira dalam elite lingkaran dalam, dengan cara berupaya untuk menahan diri dan tidak melakukan tindakan yang keras terhadap pers (Abar, 1995; Elson, 2001; Jenkins, 2010; dan Hill, 2011). Pemerintah Orde Baru, misalnya, masih memberikan suasana yang kondusif bagi kehidupan pers yang bersikap kritis sekalipun. Dalam salah satu edisi surat kabar Kompas di Jakarta, pada tanggal 16 Oktober 1970, misalnya, bahkan diberitakan bahwa 
dalam suatu kesempatan, Presiden Soeharto masih memuji tentang pers Indonesia yang sudah melangkah jauh lebih dewasa dan bisa mewujudkan peranannya sebagai kekuatan demokrasi keempat, selain Eksekutif, Legislatif, dan Yudikatif (Abar, 1995; Sen \& Hill, 2001; dan Sularto ed., 2007).

Sikap Presiden Soeharto tersebut, menurut analisa Akhmad Zaini Abar (1995), harus dimaknai karena pemerintah Orde Baru masih memiliki banyak pertimbangan, di antaranya adalah bahwa rezim yang baru ini masih membutuhkan legitimasi politik dari masyarakat; di samping untuk menganggap bahwa pemerintah Orde Baru adalah penguasa yang demokratis, sesuai dengan amanat yang diembannya yaitu: "melaksanakan UUD (Undang-Undang Dasar) 1945 dan Pancasila secara murni dan konsekuen" (Abar, 1995:69). Selain itu juga mengingat konsolidasi kekuatan negara, terutama dalam tubuh TNI-AD, masih dalam proses penyelesaian yang rumit sehingga masih merasa belum siap dalam menghadapi secara frontal untuk mengatasi protes-protes dan kritik-kritik sosial dari masyarakat yang sedang dilanda demam demokrasi. Lagi pula, di balik kritik-kritik sosial yang disampaikan oleh pers itu masih bisa ditolelir dan dianggap cukup bermanfaat sebagai alat introspeksi diri (Sundhaussen, 1987; Abar, 1995; Crouch, 1999; Jenkins, 2010; dan Hill, 2011).

Tetapi setelah tahun 1972, dengan merebaknya isu pembangunan proyek TMII (Taman Mini Indonesia Indah), seperti yang telah diuraikan sebelumnya, sikap pemerintah Orde Baru terhadap pers menjadi lain. Isu proyek TMII memang telah menumbuhkan sikap kritis dan populis, serta keberanian pers dalam mengungkapkan suara-suara ketidakpuasan dari masyarakat (Abar, 1995; Surjomihardjo et al., 2002; Aly, 2004; dan Hill, 2011). Di samping itu, proyek TMII juga telah mengundang aksiaksi protes dari mahasiswa yang, dalam pandangan pemerintah Orde Baru, semakin mengarah kepada gerakan radikalisme; dan, yang lebih fatal lagi, dinilai telah menghina marwah Ibu Negara dan Istri Presiden, Tien Soeharto, dari Madam Tien President menjadi Madam Ten Procent (Raillon, 1985; Aly, 2004; Abdulgani-Knapp, 2007; Jenkins, 2010; dan Taufik, 2014).

Sepanjang tahun 1973, dengan demikian, adalah tahun panas dalam hubungan antara pemerintah Orde Baru dengan pers dan mahasiswa, termasuk dengan mingguan Mahasiswa Indonesia di Bandung. Kini, periode "bulan madu" yang manis antara pemerintah dengan pers mununjukan tanda-tanda akan berakhir. Dan janji-janji pemerintah Orde Baru untuk memberikan kekebasan dan tanggung jawab kepada pers, nampaknya akan dicabut kembali oleh pemerintah yang berkuasa. Kebebasan pers, dalam pandangan pemerintah Orde Baru, harus disertai dengan tanggung jawab; dan tanggung jawab itu harus ditujukan kepada pemerintah, bukan kepada masyarakat (Abar, 1995; Sen \& Hill, 2001; Sularto ed., 2007; Hill, 2011; dan wawancara dengan Rachman Tolleng, 12/3/2001).

Pemerintah Orde Baru, sejak tahun 1973, mulai melakukan tindakan yang lebih keras terhadap pers. Hal itu terbukti dengan adanya pencabutan untuk sementara SIT (Surat Ijin Terbit) bagi harian Sinar Harapan di Jakarta, karena dianggap telah membocorkan rahasisa negara, yaitu isi RAPBN (Rancangan

Anggaran Pendapatan dan Belanja Negara) tahun 1973-1974, yang belum diumumkan oleh pemerintah Orde Baru secara resmi. Surat kabar Sinar Harapan adalah milik orang-orang Kristen Protestan, berbeda dengan surat kabar Kompas yang milik orang-orang Katholik, sehingga istilah KOMPAS sering diplesetkan artinya sebagai "Komando Pastur" (Malarangeng, 1992; Abar, 1995; Surjomihardjo et al., 2002; dan Sularto ed., 2007).

Dalam pada itu, munculnya peristiwa kerusuhan anti Cina di Bandung, pada tanggal 5 Agustus 1973, juga telah 
diberitakan secara kronologis oleh mingguan Mahasiswa Indonesia. Peristiwa itu disorot oleh mingguan Mahasiswa Indonesia, karena tidak hanya menggegerkan masyarakat di Bandung dan sekitarnya, tetapi juga sempat meresahkan masyarakat di kota-kota lainnya (Raillon, 1985;

Sjamsuddin, 2002; dan wawancara dengan Rachman Tolleng, 12/3/2001). Dalam hal ini, mingguan Mahasiswa Indonesia, No.371 (Agustus) tahun 1973, menurunkan berita dan analisis yang berjudul "Anatomi Peristiwa 5 Agustus 1973"; serta editorial yang berjudul "Peristiwa 5 Agustus 1973" untuk menunjukan ketidakpuasan masyarakat luas kepada pemerintah Orde Baru. ${ }^{11}$ Dan peristiwa kerusuhan anti Cina di Bandung itu merupakan peristiwa pendahuluan bagi munculnya peristiwa MALARI (Malapetaka 15 Januari) tahun 1974 di Jakarta yang lebih dahsyat lagi (Raillon, 1985; Sjamsuddin, 2002; dan Padiatra, 2015).

Akibat dari peristiwa MALARI tahun 1974 telah mendorong pemerintah Orde Baru untuk bersikap keras dan represif terhadap pers. Setelah peristiwa itu, mingguan Mahasiswa Indonesia di Bandung, bersama-sama dengan media massa lainnya, dibreidel oleh pemerintah Orde Baru (Siregar, 1983; Raillon, 1985; Abar, 1995; Surjomihardjo et al., 2002; dan Hill, 2011). Memang, sebelum peristiwa MALARI 1974 itu terjadi, mingguan Mahasiswa Indonesia, No.392 (Djanuari) 1974, menurunkan tulisan yang berjudul "Dari Malam Tirakat di Kampus UI: Kita Harus Berbuat". Dalam tulisan itu dikutip tentang adanya percakapan dalam suatu acara tirakatan (tradisi Jawa untuk berpuasa dan tidak tidur sepanjang malam), yang salah satunya dihadiri oleh Hatta Albanik, Ketua Dewan Mahasiswa UNPAD

\footnotetext{
${ }^{11}$ Lihat, misalnya, berita "Anatomi Peristiwa 5 Agustus 1973"; dan tajuk rencana "Peristiwa 5 Agustus 1973" dalam mingguan Mahasiswa Indonesia, No.371. Bandung: Agustus 1973.
}

(Universitas Padjadjaran) Bandung; dan Hariman Siregar, Ketua Dewan Mahasiswa UI (Universitas Indonesia) Jakarta, yang sepakat dan menyatakan, sebagai berikut:

[...] kita harus bergerak, para pedjabat tinggi, dan orang Tjina adalah pihak jang harus bertanggung-djawab dari situasi negara jang katjau ini. ${ }^{12}$

Pemerintah Orde Baru, kemudian, menganggap bahwa mingguan Mahasiswa Indonesia di Bandung - beserta dengan koran-koran yang lain, juga stasiun radio - telah menyebarkan isu-isu yang mengkibatkan terjadinya peristiwa MALARI tahun 1974. Pemerintah Orde Baru, akhirnya, mengambil tindakan represif dengan membreidel 10 surat kabar harian, 8 majalah dan tabloid mingguan, serta 3 buah stasiun radio. Baik SIT (Surat Ijin Terbit) ataupun SIS (Surat Ijin Siaran), yang merupakan legalisasi untuk berkomunikasi dengan masyarakat, untuk sementara atau selamanya terpaksa dicabut oleh pemerintah Orde Baru. Setelah Harian Nusantara di Jakarta, baru mingguan Mahasiwa Indonesia di Bandung, mulai hari Minggu tanggal 20 Januari 1974, SIT-nya dicabut oleh PANGKOPSKAMTIBDA (Panglima Komando Operasi Keamanan dan Ketertiban Daerah) Jawa Barat, Mayor Drs. A.D. Salam, dengan alasan bahwa mingguan ini masih terus melakukan penghasutanpenghasutan yang mengganggu keamanan dan ketertiban umum (Siregar, 1983; Raillon, 1985; Junaedhie, 1991; Abar, 1995; Surjomihardjo et al., 2002; dan Hill, 2011).

Berdasarkan Surat Keputusan LAKSUS (Pelaksana Khusus) PANGKOPSKAMTIBDA Jawa Barat itulah,

\footnotetext{
${ }^{12}$ Lihat "Dari Malam Tirakat di Kampus UI: Kita Harus Berbuat" dalam mingguan Mahasiswa Indonesia, No.392. Bandung: Djanuari 1974. Lihat juga, misalnya, kajian yang dilakukan oleh Hariman Siregar (1994); A. Yogaswara (2009); J. Lasut (2011); Ipong Jazimah (2013); dan Aditia Muara Padiatra (2015) dalam menyoroti masalah MALARI (Malapetaka 15 Januari) pada tahun 1974 tersebut.
} 
dan sesuai dengan keputusan Pemerintah Orde Baru dalam sidang kabinet terbatas pada hari Kamis tanggal 18 Januari 1974, langkah-langkah preventif dan represif pemerintah terhadap pers diambil dalam rangka untuk menjamin keamanan dan ketertiban umum, menurut versi dan kepentingan politik pemerintah Orde Baru (Harahap, 1996; Vatikiotis, 1998; Crouch, 1999; Fatah, 1999; Istyaningrum, 2004; McGlynn et al., 2007; McGregor, 2008; dan Jenkins, 2010).

\section{KESIMPULAN 13}

Tahun 1966-1974 merupakan periode yang penuh dengan gejolak dan dinamika dalam sejarah pers di Indonesia. Pers juga masih memiliki kebebasan, setelah pada periode sebelumnya, pers dikekang dan dibungkam kebebasannya oleh pemerintah Orde Lama (1959-1966). Pers Indonesia berharap agar pemerintah Orde Baru bisa mengatasi masalah-masalah ekonomi, sosial, dan politik yang telah diwarisi oleh pemerintah Orde Lama. Karena itu, halhal yang dinilai menjadi masalah bagi pemerintah Orde Baru pada masa-masa awal (1966-1974), menjadi sorotan dan kritik sosial bagi pers Indonesia.

Dalam konteks ini, mingguan Mahasiswa Indonesia di Bandung, pers yang kelahirannya didukung oleh

\footnotetext{
${ }^{13}$ Sebuah Pengakuan: Artikel ini, sebelum diterbitkan dan diubah-suai dalam bentuknya sekarang, merupakan ringkasan hasil penelitian untuk tujuan memperkaya bahan perkuliahan Sejarah Orde Baru dan Reformasi (19661998) di Departemen Pendidikan Sejarah FPIPS UPI (Fakultas Pendidikan Ilmu Pengetahuan Sosial, Universitas Pendidikan Indonesia) di Bandung. Saya mengucapkan terima kasih kepada Haji Moch Eryk Kamsori, S.Pd. dan Iing Yulianti, M.Pd., dua orang Asisten Dosen saya, yang sudah banyak membantu proses perkuliahan dengan baik dan lancar. Saya juga memberikan apresiasi yang tinggi kepada para Mahasiswa yang mengontrak matakuliah tersebut, dimana banyak pertanyaan dan komentar mereka untuk memperbaiki dan mempertajam analisis dalam artikel ini. Walau bagaimanapun, seluruh isi dan interpretasi dalam tulisan ini berada dibawah tanggung jawab akademik saya secara pribadi, dan tidak ada hubungkaitnya dengan mereka.
}

pemerintah Orde Baru, tetap bersikap kritis dalam menyoroti masalah-masalah yang membelenggu pemerintah pada masa itu, terutama adanya fenomena KKN (Korupsi, Kolusi, dan Nepotisme), dengan mencuatnya kasus yang menyangkut kedudukan SPRI (Staf Pribadi) Presiden, kasus BULOG (Badan Urusan Logistik), dan masalah pembangunan TMII (Taman Mini Indonesia Indah) di Jakarta. Mingguan Mahasiswa Indonesia mampu memberikan news and views (berita dan pandangan) yang kritis dalam menyoroti masalah-masalah tersebut; dan tidak sedikit menimbulkan dorongan semangat untuk bertindak dan bereaksi bagi sebagian masyarakat dan mahasiswa yang tidak puas terhadap pemerintah Orde Baru.

Namun, berbagai reaksi dari sebagian masyarakat dan mahasiswa yang kritis, serta didukung oleh pers - termasuk mingguan Mahasiswa Indonesia di Bandung - tidak menggoyahkan kedudukan pemerintah Orde Baru, bahkan menjadi cambuk untuk tumbuh lebih kuat dalam rangka membangun konsolidasi kekuasaan dan legitimasi pemerintahan. Hal itu terbukti bahwa pada pasca peristiwa MALARI (Malapetaka 15 Januari) tahun 1974, pemerintah Orde Baru semakin tumbuh besar dan memperkuat kedudukannya sebagai rezim yang sepertinya tidak akan tergoyahkan untuk 20 tahunan ke depan. ${ }^{14}$

\section{Referensi}

Abar, Akhmad Zaini. (1995). Kisah Pers Indonesia, 1966-1974. Yogyakarta: Penerbit LKiS.

Abdulgani-Knapp, Retnowati. (2007). Soeharto: The Life and Legacy of Indonesia's Second Presindent. Singapore: Marshall Cavendish

\footnotetext{
${ }^{14}$ Pernyataan: Saya menyatakan, dengan ini, bahwa artikel dengan seluruh isi dan interpretasinya ini adalah karya saya sendiri. Artikel ini bukan hasil plagiat, sebab semua sumber yang saya kutip dalam analisis, tercantum secara jelas dalam Referensi atau Daftar Pustaka. Artikel ini juga belum pernah dikirim, direviu, apalagi diterbitkan oleh jurnal ilmiah lainnya.
} 
International (Asia) Private Limited.

Abrar, Ana Nadhya. (1992). Pers Mahasiswa dan Permasalahan Operasionalisasinya. Yogyakarta: Penerbit Liberty.

Affan, Heyder. (2013). “Orde Baru Dibenci, Orde Baru Dirindukan" dalam BBC News Indonesia, tanggal 25 November. Tersedia secara online juga di: https://www.bbc.com/indonesia/ laporan khusus/2013/11/131125 lapsus suharto stabiltas_dulu sekarang [diakses di Bandung, Jawa Barat, Indonesia: 9 Oktober 2017].

Albach, Philip G. (1988). Politik dan Mahasiswa: Perspektif dan Kecenderungan Masa Kini. Jakarta: PT Gramedia.

Ali, Fachry et al. (1986). Beras, Koperasi, dan Politik Orde Baru. Jakarta: Pustaka Sinar Harapan.

Aly, Rum. (2004). Menyilang Jalan Kekuasaan Militer Otoriter: Gerakan Kritis Mahasiswa Bandung di Panggung Politik Indonesia, 19701974. Jakarta: Penerbit Kompas.

“Anatomi Peristiwa 5 Agustus 1973" dalam mingguan Mahasiswa Indonesia, No.371. Bandung: Agustus 1973.

Anggraeni, D.F., A. Suwirta \& F. Sarimaya. (2016). "Badan Urusan Logistik (BULOG): Dari Monopoli hingga Mekanisme Pasar, Tahun 1998-2006" dalam FACTUM, Vol.5, No.1 [April]. Tersedia secara online juga di: http://jurnal. upi.edu/file/JURNAL DEGIA FITRA A.pdf [diakses di Bandung, Jawa Barat, Indonesia: 2 Maret 2018].

Anto, J. \& P. Hasudungan Sirait. (2011). Asmara Nababan: Oase bagi Setiap Kegelisahan. Jakarta: Perkumpulan Demos. Tersedia secara online juga di: https://media.neliti.com/media/ publications/399-ID-asmara-nababan [diakses di Bandung, Jawa Barat, Indonesia: 2 Maret 2018].

Anwar, Moh Arsjad, Aris Ananta \& Ari Kuncoro [eds]. (2007). Kesan para Sahabat tentang Widjojo Nitisastro. Jakarta: Penerbit Buku Kompas.

Anwar, Yozar. (1980). Angkatan 66: Sebuah Catatan Harian Mahasiswa. Jakarta: Sinar Harapan.

Arismunandar, Satrio. (2012). "Sejarah dan Fenomena Pers Mahasiswa". Tersedia secara online di: http://www.academia.edu/4979961/ Sejarah_dan_Fenomena_Pers_Mahasiswa [diakses di Bandung, Jawa Barat, Indonesia: 9 Oktober 2017].

Ashari, Fauzan Adi. (2015). "Pasang-Surut Sejarah BULOG di Indonesia pada Tahun 1967-1998". Skripsi Sarjana Tidak Diterbitkan. Jember: Jurusan Ilmu Sejarah, Fakultas Sastera UNEJ [Universitas Negeri Jember]. Tersedia secara online juga di: http://repository.unej.ac.id/ bitstream/handle/123456789 [diakses di Bandung, Jawa Barat, Indonesia: 2 Maret 2018].
Azziz, Arif Abdul. (2006). “Analisis Impor Beras serta Pengaruhnya terhadap Harga Beras dalam Negeri”. Skripsi Sarjana Tidak Diterbitkan. Bogor: Program Studi Manajemen Agribisnis, Fakultas Pertanian IPB [Institut Pertanian Bogor]. Tersedia secara online juga di: https://repository. ipb.ac.id/jspui/bitstream/123456789/44569/1/ A06aaa.pdf [diakses di Bandung, Jawa Barat, Indonesia: 2 Maret 2018].

Basuki, Ahmad Yani. (2014). "Reformasi TNI: Pola, Profesionalitas, dan Refungsionalisasi Militer dalam Masyarakat" dalam MASYARAKAT: Jurnal Sosiologi, Vol.19, No.2 [Juli], hlm.135-166.

Both, Anne \& Peter McCawley. (1983). Ekonomi Orde Baru. Jakarta: Penerbit LP3ES, Terjemahan.

"BULOG: Peranannja Perlu Ditindjau" dalam mingguan Mahasiswa Indonesia, No.160. Bandung: Djuli 1969.

Cahyono, Heru. (1998). Pangkopkamtib Jenderal Soemitro dan Peristiwa 15 Januari '74. Jakarta: Pustaka Sinar Harapan.

Crouch, Harold. (1999). Militer dan Politik di Indonesia. Jakarta: Pustaka Sinar Harapan, Terjemahan.

Culla, Adi Suryadi. (1999). Patah Tumbuh Hilang Berganti: Sketsa Pegolakan Mahasiswa dalam Politik dan Sejarah Indonesia, 1908-1998. Jakarta: Raja Grafindo Persada.

"Dari Malam Tirakat di Kampus UI: Kita Harus Berbuat" dalam mingguan Mahasiswa Indonesia, No.392. Bandung: Januari 1974.

Denzin, Norman K. (2008). "Evolution of Qualitative Research" in Lisa M. Given [ed]. The SAGE Encyclopedia of Qualitative Research Methods, Volumes 1 \& 2. Los Angeles, London, New Delhi, and Singapore: A Sage Reference Publication.

Elson, Robert E. (2001). Suharto: A Political Biography. Cambridge, United Kingdom: Cambridge University Press.

Fatah, Eep Saefullah. (1999). Negara Orde Baru dan Pengendalian Konflik Politik, 1967-1988: Studi tentang Peristiwa Malari, Petisi 50, dan Tanjung Priok. Jakarta: Rosdakarya Bandung.

Feith, Herbert. (1964). "President Soekarno, the Army, and the Communists: The Triangle Changes Shape" in Asian Survey, Volume 4(8), pp.969-980.

Gie, Soe Hok. (1983). Catatan seorang Demonstran. Jakarta: Penerbit LP3ES.

Gie, Soe Hok. (1995). Zaman Peralihan. Yogyakarta: Yayasan Bentang Budaya.

Glassburner, Bruce. (1988). "Politik Ekonomi dan Pembangunan Orde Baru" dalam H.W. Arnandt [ed]. Pembangunan dan Pemerataan: Indonesia di Masa Orde Baru. Jakarta: Penerbit LP3S, Terjemahan. 
Harahap, Krisna. (1996). Kebebasan Pers di Indonesia: Kaitannya dengan Surat Izin. Jakarta: PT Grafiti Budi Utami.

Hill, Hal. (1997). Indonesia's Industrial Transformation. Singapore: ISEAS [Institute of South East Asian Studies].

Hill, Hal. (2002). The Indonesian Economy. Cambridge: Cambridge University Press.

Hill, David T. (2011). Pers di Masa Orde Baru. Jakarta: Yayasan Pustaka Obor.

Idris, Naswil. (1967). "Penjelundup dari Riau ke Singapura: Jang Ketjil Tertangkap, jang Besar ke Mana?" dalam mingguan Mahasiswa Indonesia, No.52. Bandung: Djuni.

Islam, Roumeen. (2006). The Right To Tell: The Role of Mass Media in Economic Development. Jakarta: The World Bank Institute.

Istyaningrum, Febrinita Dwi. (2004). "Peran ABRI sebagai Kekuatan Sosial-Politik pada Masa Orde Baru, 1966-1997”. Skripsi Sarjana Tidak Diterbitkan. Semarang: Jurusan Sejarah FIS UNNES [Fakultas Ilmu Sosial, Universitas Negeri Semarang]. Tersedia secara online juga di: [diakses di Bandung, Jawa Barat, Indonesia: 9 Oktober 2017].

Jazimah, Ipong. (2013). “MALARI: Studi Gerakan Mahasiswa Masa Orde Baru" dalam Jurnal AGASTYA, Vol.03, No.01 [Januari]. Tersedia secara online juga di: file:///C:/Users/acer/ Downloads/902-1668-1-SM.pdf [diakses di Bandung, Indonesia: 9 Oktober 2017].

Jenkins, David. (2010). Soeharto \& Barisan Jenderal ORBA: Rezim Militer Indonesia, 1975-1983. Depok: Komunitas Bambu, Terjemahan.

Junaedhie, Kurniawan. (1991). Ensiklopedia Pers Indonesia. Jakarta: PT Gramedia Pustaka Utama.

Kartodirdjo, Sartono. (1992). Pendekatan Ilmu Sosial dalam Metodologi Sejarah. Jakarta: Gramedia Pustaka Utama.

"Keprihatinan dalam Pembangunan" dalam mingguan Mahasiswa Indonesia, No.290. Bandung: Djanuari 1972.

Khoir, Anan Bahrul. (2014). "Pembangunan di Indonesia pada Masa Orde Baru". Tersedia secara online di: http://www.academia.edu/10123954/ Pembangunan di_Indonesia pada masa_Orde Baru [diakses di Bandung, Jawa Barat, Indonesia: 9 Oktober 2017].

Kuncoro, Mudrajad. (2010). Masalah Kebijakan dan Politik Ekonomika Pembangunan. Jakarta: Penerbit Erlangga.

Lasut, J. (2011). MALARI: Melawan Soeharto dan Barisan Jenderal ORBA. Depok: Yayasan Penghayat Keadilan.

Lee, Oey Hong. (1971). Indonesian Goverment and Press During Guided Democracy. London:
University of Hull.

Liddle, William. (1992). Partisipasi dan Partai Politik: Indonesia pada Masa Awal Orde Baru. Jakarta: Grafiti Press, Terjemahan.

Luiten, Jan van Zanden \& Daan Marks. (2012). Ekonomi Indonesia, 1800-2010: Antara Drama dan Keajaiban Pertumbuhan. Jakarta: PT Kompas Media Nusantara dan KITLV Jakarta, terjemahan Abdul Wahid.

Magenda, Burhan D. (1991). Gerakan Mahasiswa dan Hubungannya dengan Sistem Politik: Suatu Tinjauan. Jakarta: Penerbit LP3ES.

Mahasiswa Indonesia [Mingguan]. Bandung: 19 Juni 1966.

Mahasiswa Indonesia [Mingguan], No.2. Bandung: Djuni 1966.

Mahasiswa Indonesia [Mingguan], No.10. Bandung: Agustus 1966.

Mahasiswa Indonesia [Mingguan], No.14. Bandung: September 1966.

Mahasiswa Indonesia [Mingguan], No.41. Bandung: Maret 1967.

Mahasiswa Indonesia [Mingguan], No.308. Bandung: Mei 1972.

Malarangeng, Rizal. (1992). Pers Orde Baru: Tinjauan Isi Harian Kompas dan Suara Karya. Jakarta: Penerbit Rajawali Pers.

Mas'oed, Mohtar. (1989). Ekonomi dan Struktur Politik Orde Baru, 1966-1971. Jakarta: Penerbit LP3ES, Terjemahan.

Mas’oed, Mohtar. (1996). “Lembaga Kepresidenan dan Resep Pengendalian Politik di Indonesia" dalam Risa Noer Arfani [ed]. Demokrasi Indonesia Kontemporer. Jakarta: Grafindo Persada.

Maxwell, John. (2001). Soe Hok Gie: Pergulatan Intelektual Melawan Tirani. Jakarta: Pustaka Utama Grafiti, Terjemahan.

McDonald, H. (1980). Suharto’s Indonesia. Blackburn, Australia: Fontana Books.

McGlynn, John H. et al. (2007). Indonesia in the Soeharto Years: Issue, Incidents, and Images. Jakarta: KITLV Press.

McGregor, Katharine E. (2008). Ketika Sejarah Berseragam. Yogyakarta: Penerbit Syarikat, Terjemahan.

Milne, R.S. (1984). "Teknokrat dan Politik di Negara-negara Asia Tenggara" dalam Prisma, No.3 [Maret]. Jakarta: Penerbit LP3ES.

"Mingguan Mahasiswa Indonesia di Bandung". Tersedia secara online di: http:// koleksikemalaatmojo2.blogspot.com [diakses di Bandung, Jawa Barat, Indonesia: 9 Oktober 2017].

Moertopo, Ali. (1974). Strategi Politik Nasional. Jakarta: Penerbit CSIS.

Muhaimin, Yahya. (1982). Perkembangan Militer dalam Politik di Indonesia, 1945-1966. 
Yogyakarta: Gadjah Mada University Press.

Muhaimin, Yahya. (1990). Bisnis dan Politik: Kebijaksanaan Ekonomi Indonesia, 1950-1980. Jakarta: Penerbit LP3ES, Terjemahan.

Muhdar. (2012). Peran Pers Mahasiswa dalam Kancah Pers Indonesia. Yogyakarta: Mata Media.

Nasution, Anwar (1985). Peluang dan Tantangan Pembangunan sampai 1989. Jakarta: Penerbit Sinar Harapan.

Nasution, Lokot Zein. (2016). "Reposisi Peran dan Fungsi BULOG dalam Tata-Niaga Pangan" dalam Jurnal Kajian Pangan, Vol.21, No.1 [Maret], hlm.68-69.

Nindarsari. (1984). Implikasi Politik Penanaman Modal Jepang di Indonesia, 1970-1979. Jakarta: Penerbit FISIP UI [Fakultas Ilmu Sosial dan Ilmu Politik, Universitas Indonesia].

Notosusanto, Nugroho. (1984). Masalah Penelitian Sejarah Kontemporer. Jakarta: Inti Indayu.

Notosusanto, Nugroho et al. [eds]. (1991). Pejuang dan Prajurit: Konsepsi dan Implementasi Dwifungsi ABRI. Jakarta: Pustaka Sinar Harapan.

Novianto, Arif. (2016). "Pergulatan Gerakan Mahasiswa \& Kritik terhadap Gerakan Moral: Buku Indonesia Bergerak II". Tersedia secara online di: : https://www.researchgate.net/ publication/311737347 [diakses di Bandung, Jawa Barat, Indonesia: 2 Maret 2018].

Padiatra, Aditia Muara. (2015). "Introduction to MALARI: Dari Situasi, Aksi, hingga Rusuh pada Awal Orde Baru, 1970 - 1974" dalam Jurnal Criksetra, Vol.4, No.8 [Agustus].

"Peristiwa 5 Agustus 1973" dalam mingguan Mahasiswa Indonesia, No.371. Bandung: Agustus) 1973.

Permana, Satria. (2012). "Badai di Tengah Oil Boom: Krisis Manajemen Keuangan PERTAMINA Tahun 1974-1975". Skripsi Sarjana Tidak Diterbitkan. Depok: Program Studi Ilmu Sejarah FIPB UI [Fakultas Ilmu Pengetahuan Budaya, Universitas Indonesia]. Tersedia secara online di: http://lib.ui.ac.id/file?file=digital/20308917S42719-Badai [diakses di Bandung, Jawa Barat, Indonesia: 2 Maret 2018].

Poesponegoro, Marwati Djoened \& Nugroho Notosusanto [eds]. (1991). Sejarah Nasional Indonesia VI. Jakarta: Balai Pustaka.

Pujoalwanto, Basuki. (2014). Perekonomian Indonesia: Tinjauan Historis, Teoritis, dan Empiris. Yogyakarta: Graha Ilmu.

Raditya, Iswara N. (2018). "Ambisi Tien Soeharto dan Polemik Proyek TMII: 22 Tahun Meninggalnya Ibu Tien”. Tersedia secara online di: https://tirto.id/ambisi-tien-soeharto-danpolemik-proyek-tmii-cJwh [diakses di Bandung, Jawa Barat, Indonesia: 20 Mei 2018].
Rahmat, M. Aref. (2011). Ali Moertopo dan Dunia Intelijen Indonesia. Yogyakarta: Penerbit Narasi.

Raillon, Francois. (1985). Politik dan Ideologi Mahasiswa Indonesia: Pembentukan dan Konsolidasi Orde Baru, 1966-1974. Jakarta: Penerbit LP3ES, Terjemahan.

Rajab, Budi. (2004). "Negara Orde Baru: Berdiri di Atas Sistem Ekonomi dan Politik yang Rapuh" dalam Jurnal Sosiohumaniora, Vol.6, No.3 [November], hlm.182-202.

Ricklefs, M.C. (2008). Sejarah Indonesia Modern, 1200-2008. Jakarta: Penerbit Serambi, Terjemahan.

Roeder, O.G. (1981). Anak Desa: Biografi Presiden Soeharto. Jakarta: Haji Masagung, terjemahan A. Bar Salim \& Hadi Noor.

Saidi, Ridwan. (1989). Mahasiswa dan Lingkaran Politik. Jakarta: Lembaga Pers Mahasiswa Mapussy Indonesia.

Samego, Indria et al. (1998). Bila ABRI Berbisnis. Bandung: Penerbit Mizan.

Saragih, Juli Panglima. (2016). "Kelembagaan Urusan Pangan dari Masa ke Masa dan Kebijakan Ketahanan Pangan" dalam Jurnal Ekonomi \& Studi Pembangunan, Vol.17, No.2 [Oktober], hlm.168-192.

Sen, Krishna \& David T. Hill. (2001). Media, Budaya, dan Politik di Indonesia. Jakarta: Institut Studi Arus Informasi bekerjasama dengan Media Lintas Inti Nusantara, Terjemahan.

Singh, Bilveer. (1999). Dwifungsi ABRI: Asal-usul, Aktualisasi, dan Implikasinya bagi Stabilitas dan Pembangunan. Jakarta: PT Gramedia Pustaka Utama.

Siregar, Amir Effendi. (1983). Pers Mahasiswa Indonesia: Patah Tumbuh, Hilang Berganti. Jakarta: PT Karya Unipress.

Siregar, Hariman. (1994). Hati Nurani seorang Demonstran. Jakarta: Mantika Media Utama.

Sjamsuddin, Helius. (2002). "Rusuh di Bandung: Peristiwa 5 Agustus 1973 dalam Liputan Media Massa" dalam HISTORIA: Jurnal Kajian Sejarah dan Pendidikan Sejarah, Vol.III, No.6. Bandung: Jurusan Pendidikan Sejarah FPIPS UPI [Fakultas Pendidikan Ilmu Pengetahuan Sosial, Universitas Pendidikan Indonesia].

Sjamsuddin, Helius. (2007). Metodologi Sejarah. Yogyakarta: Penerbit Ombak.

Smith, Edward C. (1986). Pembreidelan Pers di Indonesia. Jakarta: PT Pustaka Grafitipers, Terjemahan.

Soeharto. (1989). Pikiran, Ucapan, dan Tindakan Saya: Otobiografi seperti Dipaparkan kepada G. Dwipayana dan Ramadhan K.H. Jakarta: Citra Lamtorogung Persada.

Sularto, St. [ed]. (2007). Kompas: Dari Belakang ke Depan. Jakarta: Penerbit Buku Kompas.

Sundhaussen, Ulf. (1987). Politik Militer Indonesia, 
1945-1967: Menuju Dwi Fungsi ABRI. Jakarta: Penerbit LP3ES, terjemahan Hasan Basri.

Supriyatna. (2007). "Peranan Soe Hok Gie dalam Gerakan Mahasiswa Indonesia Tahun 19601968”. Skripsi Sarjana Tidak Diterbitkan. Surakarta: FKIP UNS [Fakultas Keguruan dan Ilmu Pendidikan, Universitas Sebelas Maret]. Surjomihardjo, Abdurrachman et al. (2002). Beberapa Segi Perkembangan Sejarah Pers di Indonesia. Jakarta: Penerbit Buku Kompas.

Suwirta, Andi. (2008). “Dinamika Kehidupan Pers di Indonesia pada Tahun 1950-1965: Antara Kebebasan dan Tanggung Jawab Nasional" dalam SOSIOHUMANIKA: Jurnal Pendidikan Sains Sosial dan Kemanusiaan, Vol.1(2), November.

Syafa'at, M. Ali. (2011). Pembubaran Partai Politik: Pengaturan dan Praktik Pembubaran Partai Politik dalam Pergulatan Republik. Jakarta: Rajagrafindo Persada.

Taufik, Mohamad. (2014). "Ibu Tien Bikin Taman Mini, Pak Harto Menindak para Penentangnya" dalam Merdeka.Com. Jakarta: 25 Januari. Tersedia secara online juga di: https://www. merdeka.com/peristiwa/ibu-tien-bikin-tamanmini-pak-harto-menindak-para-penentangnya.

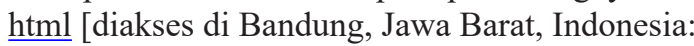
2 Maret 2018].
Tjahjono, Sukmadji Indro. (1979). "Indonesia di Bawah Sepatu Lars: Pembelaan di Muka Pengadilan Mahasiswa Bandung”. Tersedia secara online di: http://www.academia.edu/6462625/ Di Bawah Sepatu Lars [diakses di Bandung, Jawa Barat, Indonesia: 9 Oktober 2017].

Vatikiotis, Michael R.J. (1998). Indonesian Politics Under Soeharto: The Rise and Fall of the New Order. London: Routledge.

Wawancara dengan Rachman Tolleng, mantan Pendiri dan Pimpinan Redaksi Mingguan Mahasiswa Indonesia di Bandung. Wawancara dilakukan oleh seorang Mahasiswa Jurusan Pendidikan Sejarah FPIPS UPI (Fakultas Pendidikan Ilmu Pengetahuan Sosial, Universitas Pendidikan Indonesia), di Kota Bandung, pada tanggal 12 Maret 2001.

Wibisono, Christianto. (1980). Aksi-aksi TRITURA: Kisah sebuah Partnership 10 Januari - 11 Maret 1966. Jakarta: Yayasan Manajemen Informasi.

"Widjojo Nitisastro: Man of the Year 1972" dalam mingguan Mahasiswa Indonesia, No.339. Bandung: Desember 1972.

Yogaswara, A. (2009). Dalang Peristiwa 15 Januari 1974 (MALARI). Yogyakarta: Media Pressindo.

Zed, Mestika. (2004). Metode Penelitian Kepustakaan. Jakarta: Yayasan Obor Indonesia. 